\title{
1 Geochemistry of limestones deposited in various plate tectonic
}

2

3

4 Kai-Jun Zhang ${ }^{1,2 *}$, Qiu-Huan $\mathrm{Li}^{1,2}$, Li-Long Yan ${ }^{1,2}$, Lu Zeng ${ }^{1,2}$, Lu Lu $^{1,2}$, Yu-Xiu

$5 \quad$ Zhang ${ }^{1,2}$, Jie Hui ${ }^{1,2}$, Xin Jin ${ }^{1,2}$, Xian-Chun Tang ${ }^{1,2}$

6

7

\section{${ }^{1}$ Asian Tectonics Research Group and College of Earth Science, University of}

Chinese Academy of Sciences, Beijing 100049, China;

${ }^{2}$ Key Laboratory of Computational Geodynamics, Chinese Academy of Sciences, Beijing 100049, China.

\section{Abstract}

Limestone, a major part of the global sedimentary succession, susceptible to post-depositional diagenesis. Studies of limestone geochemistry are essential in the discrimination of tectonic settings of basins in which the limestones were deposited. Six Late Mesozoic and one Tertiary limestone successions of Tibet, western China, that were deposited in oceanic plateau, passive continental margin, active continental margin (fore-arc basin, back-arc basin and foreland basin) and continental inland freshwater basins were analyzed for their major, trace and rare earth element (REE) composition. This geochemical dataset, in combination with the Deep Sea Drilling Project and Ocean Drilling Program (DSDP and ODP) literature geochemical data

\footnotetext{
*Corresponding author. E-mail: kaijun@ucas.ac.cn; kai-jun@qq.com.
} 
regarding limestones deposited in open ocean environments, permitted delineation of the geochemical characteristics of limestones accumulated in these various plate tectonic settings. Major elements (e.g., $\mathrm{Fe}_{2} \mathrm{O}_{3}$ and $\mathrm{MnO}$, except for $\mathrm{CaO}$ ) of these limestone successions show large variations but are positively correlated with $\mathrm{Al}_{2} \mathrm{O}_{3}$. The REE and trace element abundances for the inland and margin limestones show a distinct positive correlation with $\mathrm{Al}_{2} \mathrm{O}_{3}$ whereas REEs and trace elements of the open ocean limestones are positively correlated with $\mathrm{MnO}$. There is a systematic increase in the magnitude of $\mathrm{Ce}$ anomalies of open ocean floor limestones away from spreading ridges to open ocean highs, to passive margins, and to active margins and inland freshwater basins. Open ocean limestones display a narrow range of $(\mathrm{La} / \mathrm{Sm})_{\mathrm{n}}$ $(0.46-0.96),(\mathrm{Sm} / \mathrm{Yb})_{\mathrm{n}}(0.25-1.96)$, and $(\mathrm{La} / \mathrm{Yb})_{\mathrm{n}}(0.23-1.38)$ but high $(\mathrm{La} / \mathrm{Ce})_{\mathrm{n}}(>1.5)$ whereas the inland + margins limestones display a much larger range $\left((\mathrm{La} / \mathrm{Sm})_{\mathrm{n}}\right.$ $(0.43-2.18),(\mathrm{Sm} / \mathrm{Yb})_{\mathrm{n}}(0.6-2.98)$ and $(\mathrm{La} / \mathrm{Yb})_{\mathrm{n}}(0.7-2.25)$ but low $(\mathrm{La} / \mathrm{Ce})_{\mathrm{n}}(<1.5)$. The inland+margins limestones are influenced geochemically upon terrigenous clasts while geochemistry of open ocean limestones is more dependent upon the flux of the hydrothermal Fe-Mn-oxyhydroxides. The control of the tectonic environments of the basins on the limestone geochemistry permits development of proxies for the discrimination of depositional regimes. The REE ratios (i.e., $\left.(\mathrm{La} / \mathrm{Ce})_{\mathrm{n}}, \mathrm{Ce} / \mathrm{Ce}{ }^{*}\right)$ along with other immobile elemental ratios (e.g., $\mathrm{Zr} / \mathrm{Ti}, \mathrm{La} / \mathrm{Sc}$ ) of limestones provide the best means for the geochemical resolution of all four depositional regimes. A $\mathrm{Rb}-\mathrm{Sr}-\mathrm{Ba}$ triangular diagram is also useful for distinguishing between four tectonic settings. Applications of the immobile geochemical proxies to 39 literature limestone 
successions demonstrate their validity, independent of diagenetic modification, metamorphism and high siliciclastic content ( $\leq 40 \mathrm{wt} . \%)$.

Keywords: limestone; geochemistry; plate tectonics; tectonic discrimination; Tibet

\section{Introduction}

Limestone, covering about $\sim 15 \%$ of the continental surface, is a major component of the global sedimentary shell and is affected by environmental and climatic influences (e.g., Wilson, 1975). Limestone successions record deposition in various tectonic settings, such as continental margin basins (e.g., Wilson, 1975), oceanic highs (e.g., Tarduno et al., 1985; Kerr, 2014; Zhang et al., 2014), oceanic floors above the carbonate compensation depth (CCD) (e.g., Liu and Schmitt, 1984, 1990; Michel et al., 1985; Wang et al., 1986; Hu et al., 1988; Liu et al., 1988; Nath et al., 1992, 1997), and in local inland freshwater lakes (e.g., Alonso-Zarza., 2003). Although primarily $\mathrm{CaCO}_{3}$, limestone typically contains a variety of trace elements that are obtained through metalliferous and terrigenous particulates and scavenging from seawater (Elderfield and Greaves, 1982; Murray et al., 1990, 1991a, 1991b, 1992; Bertram and Elderfield, 1993; Holser, 1997; Siby et al., 2008). Overview studies have demonstrated that the types and amounts of such particulates, as well as the trace elemental concentrations of seawater, generally depend on the plate tectonic environment of the basins (e.g., Murray et al., 1991a, 1991b, 1992; Holser, 1997). While lithostratigraphic, sedimentologic, palaeontologic and sequence stratigraphic studies and petrographic examination yield important data regarding depositional environment (e.g., Wilson, 1975; Zhang et al., 2004), limestones are liable to post-depositional recrystallization to obscure or obliterate primary textures. Therefore, 
the relationship between geochemistry of limestones and plate tectonics provide additional criteria for recognizing ancient plate tectonic environments and secular changes in the chemistry of seawater (e.g., Webb and Kamber, 2000). This is particularly desirable for the regimes such as orogens that have undergone intense subduction, shortening, and/or denudation so that the primary information about tectonic settings of some tectonic units has been obscured (e.g., Tarduno et al., 1985; Zhang et al., 2014). However, systematic studies relating geochemistry of limestones to their tectonic settings are lacking, despite rather infrequent literature reports concerning limestone geochemistry.

The purpose of the present paper is to present our analysis on the geochemistry of six Tibetan limestone successions (Fig. 1) deposited in the tectonic settings of oceanic plateau, passive continental margin, active continental margin and continental inland freshwater basin so as to provide a data base for our initial geochemical characterizations. In combination with the Deep Sea Drilling Project and Ocean Drilling Program (DSDP and ODP) literature geochemical data regarding limestones deposited in open ocean environments, we then delineate the geochemical characteristics of the limestones accumulated in various plate tectonic settings, in an attempt to establish the geochemical proxies for discrimination of tectonic settings in which the limestones were deposited.

\section{Plate tectonic classification of limestone sedimentary basins}

A simplified classification of the tectonic settings for the limestone sedimentation, emphasizing the proximity of the basin to a plate margin, and the type of plate boundary nearest the basin, as well as the type of the crust of the region, has been adopted (Allen and Allen, 2005). In the present study, only inland freshwater basins, 
shallow-sea continental margin basins and open oceanic basins have been considered (Table 1). Plate interactions govern the tectonic movements and composition of siliciclastic source areas, as well as the position of the basin within the plate or the plate boundary (e.g., Dickinson and Suczek, 1979; Bhatia and Crook, 1986; Allen and Allen, 2005). The shallow-sea coastal basins and open oceanic basins examined here have been divided into six general tectonic settings (Table 1).

Shallow-sea continental margin basins can be divided into unilaterally confined passive margin basin, and bilaterally confined active basins, including peripheral foreland basin, fore-arc basin, and back-arc basin (Dickinson and Suczek, 1979; Allen and Allen, 2005). The passive margin tectonic setting for limestone sedimentation occurs on Atlantic-type rifted continental margins developed along the trailing edges of continents or cratons (Dickinson and Suczek, 1979; Bhatia and Crook, 1986; Allen and Allen, 2005). Such basins are unilaterally confined by emergent stable continents with their opposite sides open to marine seaways or oceans. Such stable tectonic regimes are marked by large-areal clear, shallow waters, and likely provide best marine environments for the flourishing of marine invertebrates and the accumulation of many thick limestone successions throughout geologic history, if geographically located in warm climate zones (Wilson, 1975). The Dingri basin on the Tethyan Himalaya represents a long-lived basin developed on the stable, passive northern margin of the Gondwana supercontinent (GB in Fig. 1b; Table 1. XZBGM, 1993; Liu and Einsele, 1994).

The bilaterally confined peripheral or retroarc foreland basin, fore-arc basin, and back-arc basin are constructed on active continental margins, marked by volcanic 
rocks, and strike-slip, intensive compressional or extensional deformation (e.g., Frisch et al., 2011). Consequently, limestone sedimentary basins associated with active continental margins have diverse basement natures, geomorphic reliefs, and stress states and are bilaterally confined by (high) geomorphic reliefs which are composed of magmatic arc or deformed continental crust (Dickinson and Suczek, 1979; Bhatia and Crook, 1986; Allen and Allen, 2005. Table 1). Such instable tectonic regimes are characterized by narrow, perhaps short-lived, marine waters, significant input of siliciclastic sediments, and thus thin accumulations of limestone frequently in intercalation with siliciclastic layers. The Xigaze fore-arc basin, Cuoqin back-arc basin, and Yanshiping peripheral foreland basin are well-defined bilaterally-confined continental marginal basins in Tibet by various authors. The Xigaze fore-arc basin formed during the Cretaceous neighboring the Gangdese magmatic arc and separates from the open Neo-Tethys Ocean by accretionary wedge produced by subduction of the oceanic crust along the Yarlung-Zangpo trench (QB in Fig. 1b. Durr, 1996; Wang et al., 1999). The Cuoqin back-arc basin was built on the back of the Gangdese magmatic arc during the Early Cretaceous and was dominated by rifting during which an up-to-5-km thick limestone succession was deposited (WGZ in Fig. 1b. Zhang, 2000, 2004; Zhang et al., 2002, 2004, 2007, 2012). These two-type basins are characterized by abundant volcanic interbeds and volcanic clastics in the sedimentary rocks (Durr, 1996; Zhang et al., 2004). The Yanshiping peripheral foreland basin formed when the eastern and western Qiangtang blocks collided during the Jurassic (PO1 in Fig. 1b. Leeder et al., 1988; Zhang et al., 2006b), in which the sandstones are 
characterized by immature detrital composition of recycled orogenic source (Leeder et al., 1988; Zhang et al., 2006b).

The open oceanic basins include two types: oceanic floor basin and oceanic highs basin. Oceanic highs are generally constructed upon broad oceanic floors and are marked by thickened oceanic crust overlapped by massive mafic volcanic rocks and often occur as oceanic plateaus, oceanic islands, or aseismic ridges. The limestone successions are aggregated on the tops of such highs and are typically represented by shallow-water platform limestones ringed by patch reefs, passing laterally into basinal bituminous pelagic limestones rich in planktonic microfossils (Tarduno et al., 1985; Kerr, 2014; Zhang et al., 2014). The Mid-Cretaceous Gaize limestone suite (GZ in Fig. 1b) in central Tibet represents a type example that was deposited on the top of an oceanic plateau (the central Tibetan Meso-Tethyan oceanic plateau) and then was transported to continental margins (Zhang et al., 2014). We also use available DSDP and ODP literature data regarding limestones, including those collected from the Walvis Ridge (Wlv in Fig. 1a. Liu and Schmitt, 1984) and the Rio Grande Rise (Rgr in Fig. 1a. Quaternary-Upper Eocene; Hu et al., 1988) of the South Atlantic Ocean and from the Shatsky Rise of the Pacific Ocean (Stsk in Fig. 1a. Cretaceous/Tertiary boundary; Michel et al., 1985) for comparison. The oceanic floor basin that deposits limestones occurs above the CCD, and often receives deposition of thin lamination of limestone rich in planktonic microfossils. We use DSDP and ODP literature data of limestones collected from the Indian Ocean floor (Cenozoic; Liu and Schmitt, 1990) and the central Pacific Ocean floor (Quaternary-Upper Cretaceous; Liu et al., 1988) 
as data base (Fig. 1a; Table S1).

The continental interior inland lakes are fresh waters constructed on continental crust and are characterized by feed in abundant terrigenous clasts. The freshwater limestones are deposited on such tectonic regime are small areal and are generally intercalated with siliciclastic rocks. We use the Tertiary Wuli inland basin (WLB in Fig. 1b) and the Mid-Cretaceous Baishi inland basin (D1030 in Fig. 1b), both built on the Songpan-Ganzi complex in the northern-eastern Tibetan plateau (Leeder et al., 1988; Wang et al., 2008).

\section{Samples, analytical techniques and termination}

Tibetan limestone samples for the present study were selected based on the following four criteria principally established by Webb and Kamber (2000) and Kamber and Webb (2001): (1) the samples with microscopically visible clay or intercalated with shales were avoided; (2) those samples with minor $\mathrm{SiO}_{2}$ of insoluble residues examined in acid dissolution and major-elemental analysis were selected so as to avoid clastic detritus; (3) the samples that contain dolomite, a diagenetic mineral in the limestones, were avoided; and (4) all samples lack evidence for hydrothermal alteration and mineralization, fluid inclusions, and secondary porosity.

The fresh samples were powdered to 200 mesh in an agate mill to avoid contamination. Fused-glass discs were prepared for major-elemental analysis by ARL9800XP+ X-Ray fluorescence at the Center of Modern Analysis of the Nanjing University. Accuracy is better than $5 \%$ for major elements. Loss of ignition (LOI), 
which consists principally of $\mathrm{CO}_{2}$, was determined at $980^{\circ} \mathrm{C}$ for 90 minutes. Trace element concentrations, including rare-earth elements (REEs), were obtained with standard Inductively Coupled Plasma-Mass Spectrometer (ICP-MS) procedures at Aurora M90 ICP-MS and Element XR HR-ICP-MS, at the State Key Laboratory of Mineral Deposit Research, the Nanjing University, as described in detail by Gao et al. (2003), Zhang (2004), and Zhang et al. (2004, 2012) (see Appendix A for limited and blank values). Samples $(50 \mathrm{mg}$ ) were cleaned in ultra-pure water before dissolution in $1 \mathrm{~mL}$ of $15 \mathrm{~N}$ double-distilled $\mathrm{HNO}_{3}$. The reproducibility of measurements, based on

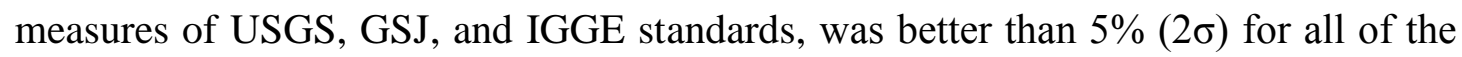
REEs, and the analytical error is typically $2-4 \%(2 \sigma)$ for elements $>10 \mathrm{ppm}$ and better than $8 \%$ for those $<10 \mathrm{ppm}$ (Appendix B). All the geochemical data are presented in Table S1. Pearson Correlation Coefficient $r$ is used for a statistical measure of linear dependence between two elements or elemental ratios (Table S2).

The REEs are divided by atomic number into three fractions: light REEs (LREE), including elements $\mathrm{La}, \mathrm{Ce}, \mathrm{Pr}$, and Nd; middle REEs (MREE), including elements Sm, $\mathrm{Eu}, \mathrm{Gd}, \mathrm{Tb}$, Dy, and Ho; and heavy REEs (HREE), including elements Er, Tm, Yb, and Lu. All REE abundances and ratios used in this paper have been normalized (subscript $\mathrm{n}$ ) to those of the Post-Archean Australian Shale (PAAS: Taylor and McLennan, 1985). Ce often behaves differently from other REEs, owing to its oxidation in some waters to relatively insoluble $\mathrm{Ce}$ (IV) precipitated in form of $\mathrm{CeO}_{2}$ (e.g., Elderfield and Greaves, 1982). The Ce anomaly is used to assess relative behavior of Ce with respect to the neighboring LREEs, and is defined by the ratio 
$\mathrm{Ce} / \mathrm{Ce}^{*}=\left(\mathrm{Ce}_{\text {Sample }} / \mathrm{Ce}_{\mathrm{PAAS}}\right) / \mathrm{Ce}^{*}$, with $\mathrm{Ce}^{*}$ obtained by linear interpolation between shale-normalized La and Nd values, in view of general absence of Pr in literature data regarding limestones collected from open oceanic environments (e.g., Liu and Schmitt, 1984, 1990; Michel et al., 1985; Wang et al., 1986; Hu et al., 1988; Liu et al., 1988).

Likewise, the $\mathrm{Eu}$ anomaly is defined by the ratio $\mathrm{Eu} / \mathrm{Eu}^{*}=\left(\mathrm{Eu} \mathrm{Sample} / \mathrm{Eu}_{\mathrm{PAAS}}\right) / \mathrm{Eu}^{*}$, and $\mathrm{Eu}^{*}$ is obtained by linear interpolation between shale-normalized $\mathrm{Sm}$ and $\mathrm{Tb}$ values due to absence of Gd in literature data (e.g., Liu and Schmitt, 1984, 1990; Michel et al., 1985; Wang et al., 1986; Hu et al., 1988; Liu et al., 1988). The obtained $\mathrm{Ce}$ and $\mathrm{Eu}$ anomalies are nearly the same as the calculations by linear interpolations between shale-normalized La and Pr values or between shale-normalized Sm and Gd, because of coupling between $\mathrm{Nd}$ and $\mathrm{Pr}$ and between $\mathrm{Gd}$ and $\mathrm{Tb}$, which are confirmed have a negative $\mathrm{Ce}$ or Eu anomaly. Variations in behavior across the REE spectrum are indicated by: (1) the degree of LREE enrichment with respect to HREE, defined as the ratio $(\mathrm{La} / \mathrm{Yb})_{\mathrm{n}}=\left(\mathrm{La}_{\text {Sample }} / \mathrm{La}_{\text {PAAS }}\right) /\left(\mathrm{Yb}_{\text {Sample }} / \mathrm{Yb}_{\text {PAAS }}\right),(2)$ the degree of LREE enrichment with respect to MREE, defined as the ratio $(\mathrm{La} / \mathrm{Sm})_{\mathrm{n}}=(\mathrm{La}$ Sample $/ \mathrm{La}$ PAAS $) /(\mathrm{Sm}$ Sample/Sm PAAS $)$, and (3) the degree of MREE enrichment with respect to HREE, defined as the ratio $(\mathrm{Sm} / \mathrm{Yb})_{\mathrm{n}}=\left(\mathrm{Sm}_{\text {Sample }} / \mathrm{Sm}_{\mathrm{PAAS}}\right) /\left(\mathrm{Yb}_{\text {Sample }} / \mathrm{Yb}_{\mathrm{PAAS}}\right)$.

The pseudo lanthanide yttrium (Y) is inserted between Ho and Dy in the REE pattern according to its identical charge and similar radius (REE+Y pattern; Bau, 1996).

\section{Limestone geochemistry}


In the discussion of this section, we include the analyses of major, trace and rare

earth elements of six limestone successions by this study as well as the Deep Sea Drilling Project and Ocean Drilling Program (DSDP and ODP) literature geochemical data regarding limestones deposited in open ocean environments.

\subsection{Major elements}

All the limestones included in the limestone geochemical dataset are limited within $<10$ wt.\% for their non-CaO-LOI compositions $\left(=\mathrm{SiO}_{2}+\mathrm{TiO}_{2}+\mathrm{Al}_{2} \mathrm{O}_{3}+\mathrm{Fe}_{2} \mathrm{O}_{3}+\mathrm{MnO}+\mathrm{MgO}+\mathrm{Na}_{2} \mathrm{O}+\mathrm{K}_{2} \mathrm{O}+\mathrm{P}_{2} \mathrm{O}_{5}\right)$. In most of the limestones, $\mathrm{CaO}$ concentrations are larger than 47 wt.\% (Table S1). The samples collected from the peripheral foreland basin (PO1 in Fig. 1b), whose surroundings could have large relief elevations due to the continental collision among the Qiangtang blocks (e.g., Zhang et al., 2006b), have the largest non-CaO-LOI compositions, with an average of $8.09 \pm 1.86 \mathrm{wt} . \%$. The inland limestones have second largest non-CaO-LOI compositions (on average $7.85 \mathrm{wt} . \%$ ) but with a much larger variation $( \pm 4.53$ wt.\%) and the samples from the two inland basins show different, large, non-CaO-LOI ranges. In contrast, the oceanic plateau limestones have the lowest non-CaO-LOI average (1.49 $\pm 0.61 \mathrm{wt} . \%)$. The samples collected from fore-arc, inland, back-arc, and passive margin basins have similar non-CaO-LOI averages (4.45-5.6 wt.\%). Among these basins, the peripheral foreland basin has largest major-element contents, except for $\mathrm{MgO}$ which is greater in samples from the oceanic plateau (Table S1). This could be attributed to the eruption of high-Mg lava while limestones accumulated (Zhang et al., 2014) rather than to diagenesis as dolomite is not present. 
The Ca is dominantly of biogenic origin and, regardless of its original distribution,

253

254 is primarily a dilutant of all other constituents, as evidenced by its strongly negative correlations with all other major and trace elements (Table S2). $\mathrm{Al}_{2} \mathrm{O}_{3}$ contents are invariant with respect to $\mathrm{Fe}_{2} \mathrm{O}_{3}$ for the inland limestones (Fig. 2a) but these two variables display positive correlation for the marine limestones (Fig. 2a, b; correlation coefficient $r=0.76$ ). In contrast, $\mathrm{Al}_{2} \mathrm{O}_{3}$ contents generally have a positive correlation with $\mathrm{MnO}$ for all the limestones $(\mathrm{r}=0.48)$, indicating that $\mathrm{Fe}_{2} \mathrm{O}_{3}$ and $\mathrm{MnO}$ are at least partially controlled by clay minerals but metalliferous hydrothermal input to the limestone geochemistry has a significant contribution. For the inland freshwater limestones and continental marginal marine limestones, $\mathrm{P}_{2} \mathrm{O}_{5}$ contents are well correlated with $\mathrm{TiO}_{2}(r=0.36-0.80), \mathrm{Fe}_{2} \mathrm{O}_{3}(r=0.53-0.66)$ and $\mathrm{K}_{2} \mathrm{O}(r=0.52-0.77)$ (Table S2), implying that some, maybe most, of the $\mathrm{P}_{2} \mathrm{O}_{5}$ contents in these limestones may not be biogenic, because $\mathrm{TiO}_{2}$ and $\mathrm{K}_{2} \mathrm{O}$ are principally derived from aluminosilicate clastics and $\mathrm{Fe}_{2} \mathrm{O}_{3}$ from hydrothermal $\mathrm{Fe}-\mathrm{Mn}$-oxyhydroxides (e.g., Murray, 1994).

Therefore, the major-elemental geochemistry of the limestones is largely controlled by the distance away from the continent and the topographic elevation as well as the volcanism, in a word, by the tectonic environments of the basins. Except for $\mathrm{CaO}$ and $\mathrm{MgO}$, all the major elements are well correlated positively with each other.

\subsection{Rare-earth elements}

\subsubsection{Total REE abundances}

Total REE abundances ( $\mathrm{REE}$ ) of the limestones are generally lower by one or two orders of magnitude when compared to the PAAS. REE in the limestones 
increases from minimum values of $1.31 \mathrm{ppm}$ at the oceanic plateau to $10-30 \mathrm{ppm}$ along the continental margins and in the continental interior (Table S1). The limestones from various plate tectonic settings have changeable REE concentrations and markedly different patterns (Figs. 3-5). Moreover, the limestones from the same plate tectonic setting also have obvious undulation of REE concentrations but exhibit generally similar REE patterns (Figs. 3-5). The $\Sigma$ REE for the inland + margins limestones are distinctly positively correlated with $\mathrm{SiO}_{2}, \mathrm{Al}_{2} \mathrm{O}_{3}, \mathrm{TiO}_{2}$ and $\mathrm{Fe}_{2} \mathrm{O}_{3}$ ( Fig. $6 \mathrm{a}-\mathrm{d} ; r=0.62,0.48,0.67,0.45$, respectively; Table $\mathrm{S} 2$ ), showing the control of detrital siliciclastic fraction on the REE. In contrast, the $\Sigma$ REE for the open ocean (floor + high) limestones only is positively correlated with $\mathrm{MnO}(r=0.58)$ but forms scatter with other major elements, indicating the control of Mn-oxyhydroxides on the REE. However, individual open ocean basins display definite linear trends between REE and $\mathrm{Fe}_{2} \mathrm{O}_{3}$ (Fig. 6b), which could be attributed to interoceanic variation in rare earth, major, and trace element depositional chemistry of sediments (e.g., Murray et al., 1992). Should explain trends and differences between trends for Open Ocean suites.Considering limestones from all environments, the $\Sigma$ REE is in a strongly negative correlation with $\mathrm{CaO}$ (Table S2), affirming the dilatation of $\mathrm{CaO}$. In particular, the back-arc basin limestones have the lowest $\Sigma$ REE among the continental margin limestones, which may be related to an inverse dependence on sedimentation rate, whose high sedimentation rate as stated above (Zhang et al., 2004) could have diluted and minimized the sediment's capacity to adsorb REE from seawater (e.g., Ruhlin and Owen, 1986). 


\subsubsection{Cerium anomalies}

Similar to the changing trend of $\mathrm{Ce}$ anomalies $\left(\mathrm{Ce} / \mathrm{Ce}^{*}\right)$ observed in waters and cherts as well as fine-grained marine sediments (see Murray et al., 1991a for a review), the magnitude of the $\mathrm{Ce}$ anomalies of the limestones exhibits a distinct increase from spreading ridge to continental coastal sea. In the diagrams of Ce/Ce* vs. $\mathrm{Al}_{2} \mathrm{O}_{3}, \mathrm{Fe}_{2} \mathrm{O}_{3}$ and $\mathrm{MnO}$ (Fig. 7a-c), all exhibit good separation between the open ocean samples and the inland + margins samples. The $\mathrm{Ce} / \mathrm{Ce} *$ values are the lowest $(\sim 0.29 \pm 0.14)$ in the spreading ridge-influenced regime (open ocean floor) and trend to successively higher increasing terrigenous influences (Fig. 7a-c; Table S1). The limestones deposited on the open ocean highs have slightly higher $\mathrm{Ce} / \mathrm{Ce}^{*}$ average $(\sim 0.34)$ than those on the ocean floors but with a larger range $( \pm 0.28)$; the limestones on active margins values $(\sim 1.1)$ in the active margin limestones with decreasing metalliferous and $(\sim 1.1-1)$ have obviously larger $\mathrm{Ce} / \mathrm{Ce}^{*}$ values $(\sim 0.79)$ than those on passive margins but can hardly be distinguished from those on inland basins, showing that the passive margin limestones are less affected by terrigenous material (Fig. 7a-c; Table S1). Therefore, the magnitudes of the $\mathrm{Ce}$ anomaly in these limestones are controlled dominantly by the amounts of included metalliferous material and direct terrigenous input. Thus, the limestones can be classified into two groups based on the variation trend of the $\mathrm{Ce} / \mathrm{Ce}^{*}$ ratios: inland + margins vs. open ocean, depending on proximity of the basin to a continental plate margin (Fig. 7a-c). The former group have obviously higher $\mathrm{Ce} / \mathrm{Ce}$ * ratios (lowest limit $~ 0.55$ ) than the latter group (Figs. 7-9). 
Furthermore, these two groups separately exhibit some consistence regarding the Ce anomalies; for example, the open ocean limestones have a positive $\mathrm{Ce} / \mathrm{Ce}{ }^{*}-\mathrm{Fe}_{2} \mathrm{O}_{3}$ correlation $(\mathrm{r}=0.29)$ while the inland+ margins limestones form a scatter between Ce/Ce* ratios and $\mathrm{Fe}_{2} \mathrm{O}_{3}$ concentrations (Fig. 7b; Table S2). The Ce/Ce* ratios of all the limestones generally have a positive correlation with the $\mathrm{Al}_{2} \mathrm{O}_{3}$ concentrations $(\mathrm{r}=0.35)$ but have no correlation with the $\mathrm{MnO}$ concentrations (Fig. 7a, c). Plots of $\mathrm{Ce} / \mathrm{Ce} *$ ratios against $\Sigma \mathrm{REE} / \mathrm{Al}_{2} \mathrm{O}_{3}$ ratios to evaluate detrital siliciclastic influence in view of refractory element $\mathrm{Al}$ overwhelmingly of detrital siliciclastic provenance (Chen et al., 2015), again point out an obviously negative correlation between Ce anomalies and the detrital siliciclastic abundances ( $r=-0.56$; Fig. 8a).

For the marine limestones, the Ce concentrations obviously are positively correlated with $\mathrm{Al}_{2} \mathrm{O}_{3}, \mathrm{Fe}_{2} \mathrm{O}_{3}$ and $\mathrm{MnO}(r=0.81,0.73,0.67$, respectively), and the $\mathrm{Ce}$ anomalies are weakly correlated positively with $\mathrm{Al}_{2} \mathrm{O}_{3}$ and $\mathrm{MnO}(r=0.33,0.35$, respectively) (Table $\mathrm{S} 2$ ), indicating that $\mathrm{Ce}$ in these rocks is controlled by both terrigenous and metalliferous input. In contrast, the Ce concentrations of the inland limestones are strongly positively correlated with $\mathrm{TiO}_{2}, \mathrm{Al}_{2} \mathrm{O}_{3}$, and $\mathrm{K}_{2} \mathrm{O}(\mathrm{r}=0.73,0.74$, 0.76, respectively), and their Ce anomalies are strongly positively correlated with $\mathrm{TiO}_{2}, \mathrm{Fe}_{2} \mathrm{O}_{3}, \mathrm{MnO}, \mathrm{MgO}, \mathrm{K}_{2} \mathrm{O}$, and $\mathrm{P}_{2} \mathrm{O}_{5}(r=0.74,0.64,0.91,0.79,0.69,0.98$, respectively) (Table S2), reflecting that the Ce anomalies are controlled by multiple factors (such as terrigenous and hydrothermal inputs) although their concentrations are dominated by terrigenous clay particles. For all the limestones, $\mathrm{Ce} / \mathrm{Ce}$ * is positively correlated with the relative enrichment of LREE over MREE and HREE 
343

344

( $r=0.57,0.62$, respectively) (Fig. 9; Table S2). Regression between $\mathrm{Ce} / \mathrm{Ce}^{*}$ and $(\mathrm{La} / \mathrm{Ce})_{\mathrm{n}}$ (Fig. 9d) shows a statistically significant relationship $\left(\mathrm{y}=1.0048 \mathrm{x}^{-1}\right.$, $\left.r^{2}=0.9688\right)$. It may relate to the exponential drop-off in sedimentation rate away from spreading ridges during seafloor spreading, which controls rate of uptake of $\mathrm{Ce}$ and $\mathrm{La}$, and differing rates of uptake may contribute to trend.

The back-arc basin samples, which have largest burial rate as shown by a >-3.3-km-thick limestone-dominated sedimentary succession deposited during an interval of $\sim 20 \mathrm{Myr}$ at the Mid-Cretaceous (Zhang et al., 2004), have the lowest $\mathrm{Ce} / \mathrm{Ce}^{*}$ values among the active margin limestones (Table S1), showing that the overall burial rate also is a critical factor that controls the $\mathrm{Ce} / \mathrm{Ce}^{*}$ magnitudes as observed in chert and other fine-grained marine sedimentary rocks by Murray et al. (1991a).

\subsubsection{Europium anomalies}

The inland limestones have the most pronounced Eu enrichment (averagely $\left.\mathrm{Eu} / \mathrm{Eu}^{*}=3.46\right)$ with large undulation $( \pm 3.28)$, that is, different inland basins have apparently various $\mathrm{Eu} / \mathrm{Eu}^{*}$ ranges. The foreland limestones have the second largest $\mathrm{Eu} / \mathrm{Eu}^{*}$ average of $1.71 \pm 0.76$. In contrast, the fore-arc limestones have the lowest $\mathrm{Eu} / \mathrm{Eu}^{*}$ values $(0.99 \pm 0.17)$ whereas the limestones from other tectonic settings have similar Eu anomalies (averagely 1.12 to 1.24 ). Of the limestones deposited on open oceanic environments, those on the oceanic highs have obviously higher Eu/Eu* values $(1.24 \pm 0.54)$ than those on the oceanic floors $(1.12 \pm 0.18)$ (Fig. 10; Table S1).

For the inland limestones, their Eu concentrations are strongly to weakly 
correlated positively with all the major elements except $\mathrm{CaO}$ (Table S2), indicating that Eu in these rocks is controlled by both terrigenous and metalliferous input. Their $\mathrm{Eu}$ anomalies are obviously correlated positively with $\mathrm{MgO}, \mathrm{MnO}, \mathrm{P}_{2} \mathrm{O}_{5}, \mathrm{Ce} / \mathrm{Ce}$ * (Fig. $11)$, and $(\mathrm{La} / \mathrm{Sm})_{\mathrm{n}}(\mathrm{r}=0.64,0.59,0.67,0.57$, respectively $)$, but negatively correlated with $(\mathrm{Sm} / \mathrm{Yb})_{\mathrm{n}}(\mathrm{r}=-0.52)$ (Table S2). The En enrichment in the inland limestones could be ascribed to enhanced dissolution from suspended riverine particles and higher stability in freshwater solution (Goldstein and Jacobsen, 1988). For the foreland limestones, the Eu concentrations are negatively correlated with $\mathrm{TiO}_{2}, \mathrm{Al}_{2} \mathrm{O}_{3}$, $\mathrm{Fe}_{2} \mathrm{O}_{3}$ (Fig. 10a, b), and $\mathrm{K}_{2} \mathrm{O}(\mathrm{r}=-0.33,-0.58,-0.48,-0.61$, respectively) but positively correlated with $\mathrm{MnO}$ (Fig. $10 \mathrm{c}$ ), $\mathrm{MgO}, \mathrm{Na}_{2} \mathrm{O}, \mathrm{P}_{2} \mathrm{O}_{5}$, and $\mathrm{CaO}(r=0.67,0.43$, $0.36,0.44,0.61$, respectively), and the Eu anomalies are positively correlated with $\mathrm{CaO},(\mathrm{La} / \mathrm{Sm})_{\mathrm{n}},(\mathrm{La} / \mathrm{Yb})_{\mathrm{n}}$, and $\mathrm{Y} / \mathrm{Ho}(r=0.75,0.45,0.45,0.68$ respectively $)$, but negatively correlated with $\mathrm{TiO}_{2}, \mathrm{Al}_{2} \mathrm{O}_{3}$ (Fig. 10a), $\mathrm{K}_{2} \mathrm{O}$, and Ce/Ce* (Fig. 11) $(r=-0.56$, $-0.64,-0.59,-0.64$, respectively) (Table S2). Therefore, the positive Eu anomalies observed for the foreland limestones in the normalized patterns might be caused by feldspars contributed by mafic rocks likely supplied from the ophiolite suites in the nearby suture zones (e.g., Zhang et al., 2006b). In addition, these Eu anomalies also might be controlled by the amount of bioapatite, which relates to seawater clarity advantageous to flourishing of marine invertebrates. For the fore-arc limestones, the Eu concentrations are strongly positively correlated with all the major elements except $\mathrm{CaO}$, and the Eu anomalies are negatively correlated with $\mathrm{Ce} / \mathrm{Ce} *,(\mathrm{La} / \mathrm{Sm})_{\mathrm{n}}$, and $(\mathrm{La} / \mathrm{Yb})_{\mathrm{n}}(r=-0.67,-0.87,-0.64$, respectively), but positively correlated with 
$388(\mathrm{Sm} / \mathrm{Yb})_{\mathrm{n}}(r=0.39)$ (Table S2). Compared to the limestones on the oceanic floors $389(\mathrm{r}=0.41)$, the Eu concentrations of the limestone on the oceanic highs are much more 390 strongly correlated positively with the $\mathrm{MnO}(\mathrm{r}=0.91)$, reflecting that the positive $\mathrm{Eu}$ 391 anomalies of the limestones may be caused by an increased oceanic input of 392 hydrothermally emanated metalliferous fluids at oceanic highs.

393 For the relationship between $\mathrm{Eu} / \mathrm{Eu}^{*}$ and $\mathrm{Ce} / \mathrm{Ce}^{*}$ ratios, two groups of the 394 limestones can be easily distinguished as well: these two ratios have a distinct positive 395 correlation $(r=0.39)$ for the inland+margins limestones while they form a scatter for 396 the open ocean limestones (Fig. 11).

397

\subsubsection{LREEs, MREEs, and HREEs}

The limestones again can be classified into two groups based on the consistence of LREEs, MREEs, and HREEs: inland + margins vs. open ocean, reflecting control of REE contents by proximity of the basin to a continental plate margin. For example, the open ocean limestones have a narrow range of LREE/MREE, MREE/HREE, and LREE/HREE ratios $\left((\mathrm{La} / \mathrm{Sm})_{\mathrm{n}}, 0.46-0.96 ;(\mathrm{Sm} / \mathrm{Yb})_{\mathrm{n}}, 0.25-1.96 ;(\mathrm{La} / \mathrm{Yb})_{\mathrm{n}}, 0.23-1.38\right)$ whereas the inland + margins limestones display a much larger range $\left((\mathrm{La} / \mathrm{Sm})_{\mathrm{n}}\right.$, 0.43-2.18; $\left.(\mathrm{Sm} / \mathrm{Yb})_{\mathrm{n}}, 0.6-2.98 ;(\mathrm{La} / \mathrm{Yb})_{\mathrm{n}}, 0.7-2.25\right)$ (Figs. 12-14; Table S1). The LREE/HREE and MREE/HREE ratios $(\mathrm{La} / \mathrm{Yb})_{\mathrm{n}}$ and $(\mathrm{Sm} / \mathrm{Yb})_{\mathrm{n}}$ for the open ocean limestones have a distinct positive correlations with $\mathrm{Al}_{2} \mathrm{O}_{3}(r=0.36,0.40)$ and $\mathrm{Fe}_{2} \mathrm{O}_{3}$ $(r=0.36,0.36)$ contents, respectively; whereas these four-pair values form scatters for the inland + margins limestones (Figs. 12, 13). However, MREE/HREE ratios 
$\left((\mathrm{Sm} / \mathrm{Yb})_{\mathrm{n}}\right)$ for the inland limestones have a distinct negative correlations with $\mathrm{Fe}_{2} \mathrm{O}_{3}$ $(r=-0.45)$ (Fig. 13c). LREE/MREE ratios $\left((\mathrm{La} / \mathrm{Sm})_{\mathrm{n}}\right)$ for the open ocean limestones have a distinct negative correlations with $\mathrm{MnO}$ contents $(r=-0.33)$ whereas these two-pair values form a scatter for the inland + margins limestones (Fig. 14b).

For the La anomalies, $(\mathrm{La} / \mathrm{Ce})_{\mathrm{n}}$, the limestones are easily distinguished into two groups again: the inland +margins group with low $(\mathrm{La} / \mathrm{Ce})_{n}(<1.5)$ while the open ocean group generally above this value (1.5. Fig. 9d). Plot of $(\mathrm{La} / \mathrm{Ce})_{\mathrm{n}}$ against ratios of terrigenous (indicated by $\mathrm{Al}_{2} \mathrm{O}_{3}$ ) and metalliferous (indicated by $\mathrm{Fe}_{2} \mathrm{O}_{3}$ ) end-member sources (Murray, 1994) better illustrates such differentiation and that $(\mathrm{La} / \mathrm{Ce})_{\mathrm{n}}$ is not correlated with terrigenous or metalliferous sources (Fig. 15). On the three diagrams of La anomalies vs. LREE/MREE, LREE/HREE, MREE/HREE ratios, respectively, the inland + margins limestones and the open ocean limestones are plotted into two distinct fields: these two fields are differentiated from each other not only by distinct $(\mathrm{La} / \mathrm{Ce})_{\mathrm{n}}$ values but also by far larger $(\mathrm{La} / \mathrm{Sm})_{\mathrm{n}},(\mathrm{La} / \mathrm{Yb})_{\mathrm{n}}$ and $(\mathrm{Sm} / \mathrm{Yb})_{\mathrm{n}}$ values of the inland + margins group (Fig. 16). The La anomalies display a strongly negative correlation with the Ce anomalies ( $r=-0.76$; Fig. 9d).

There are close relations between the ratios of LREEs, MREEs, and HREEs. For example, the LREE/HREE ratios for all the limestones are strongly positively correlated with the MREE/HREE and LREE/MREE ratios, respectively $(r=0.63,0.64)$ (Fig. 17a, b; Table S2). In contrast, the LREE/MREE ratios for all the limestones are weakly negatively correlated with the MREE/HREE ratios $(r=-0.20)$ but these two-pair ratios have strongly negative correlation for the inland +margins limestones 
$(r=-0.58)$ (Fig. 17a, b; Table S2).

For the relationship between the ratios of LREEs, MREEs, and HREEs and the $\mathrm{Ce} / \mathrm{Ce}^{*}$ ratios, the differentiation are obvious between the inland+margins and open ocean limestones (Fig. 9a-c). For example, $(\mathrm{La} / \mathrm{Sm})_{\mathrm{n}}$ are strongly positively but $(\mathrm{Sm} / \mathrm{Yb})_{\mathrm{n}}$ are distinctly negatively correlated with $\mathrm{Ce} / \mathrm{Ce}^{*}$ for the inland+margins limestones ( $r=0.79$ and -0.64 , respectively); in contrast, these two pairs form a scatter for the open ocean limestones (Fig. 9a-c; Table S2).

To summarize, the limestones deposited in open ocean environments (floors and highs) are characterized by three main features: pronounced $\mathrm{Ce}$ depletion $\left(\mathrm{Ce} / \mathrm{Ce}^{*}\right.$, $0.33 \pm 0.14)$, HREE enrichment $\left((\mathrm{Yb} / \mathrm{La})_{\mathrm{n}}, 1.49 \pm 0.21\right)$, and positive $\mathrm{La}$ anomaly, and thus they display a remarkably similar rightly-inclined pattern in the normalized spidergrams (Fig. 3). Such REE pattern is quite similar to typical seawater REE pattern (e.g., de Baar et al., 1991; Bau and Dulski, 1996), indicating that scavenging from seawater is a dominant mechanism for these limestones to obtain their REEs from open ocean environments. However, minor of them are of slight MREE enrichment, which can be attributed to preferential adsorption of LREEs and HREEs to Mn- and Fe-oxyhydroxides, respectively (e.g., Shields and Webb, 2004).

The limestones sampled from various marginal basin environments cannot be easily distinguished between each other in the normalized patterns (Fig. 4). Generally, they have MREE-bulge signatures $\left((\mathrm{Sm} / \mathrm{La})_{\mathrm{n}}, 1.01 \pm 0.21 ;(\mathrm{Sm} / \mathrm{La})_{\mathrm{n}}, 1.31 \pm 0.57\right)$, which are likely due to preferential, nonquantitative MREE uptake of sedimentary apatite as viewed from the weak negative $(\mathrm{La} / \mathrm{Sm})_{n}-\mathrm{P}_{2} \mathrm{O}_{5}$ correlation $(r=-0.32)$ and weak 
positive $(\mathrm{Sm} / \mathrm{Yb})_{\mathrm{n}}-\mathrm{P}_{2} \mathrm{O}_{5}$ correlation $(r=0.25)$ and/or post-depositional REE exchange with non-detrital components and uptake of REE from host sediments (e.g., Byrne et al., 1996; Shields and Webb, 2004). Plots of $(\mathrm{La} / \mathrm{Sm})_{\mathrm{n}},(\mathrm{Sm} / \mathrm{Yb})_{\mathrm{n}}$ and $(\mathrm{La} / \mathrm{Yb})_{\mathrm{n}}$ ratios against $\Sigma \mathrm{REE} / \mathrm{Al}_{2} \mathrm{O}_{3}$ ratios illustrate the influence of detrital siliciclastic matter on the relative abundances of various REE fractions (Fig. 18).

The limestones collected from two inland basins display sharply contrasting REE $+Y$ patterns: those from the Baishi basin have quite flat or slight MREE-bulge pattern whereas those from the Wuli basin have pronounced Eu positive anomalies $\left(\mathrm{Eu} / \mathrm{Eu}^{*}, 3.74-13.01\right)$ and strong or weak $\mathrm{Y}$ positive anomalies (Fig. 5). The flat distribution of the Baishi limestones signifies predominantly terrigenous siliciclastic influence; in contrast, the Eu peaks of the Wuli limestones could be a consequence of plagioclase enrichment. However, the positive $\mathrm{Y}$ anomalies of some Wuli limestones (Fig. 5), and thus their super-chondritic Y/Ho ratios, are incompatible with the viewpoint that such signature is a characteristic of open ocean water (e.g., Kawabe et al., 1991; Bau, 1996; Bau and Dulski, 1996; Bau et al., 1996).

\subsection{Trace elements}

Similar to the REEs, the trace elements for the inland + margins limestones are generally controlled by detrital siliciclastic fractions viewed by their positive correlations with $\mathrm{Al}_{2} \mathrm{O}_{3}, \mathrm{TiO}_{2}$, and $\mathrm{Fe}_{2} \mathrm{O}_{3}(r=0.31-0.98)$, except for $\mathrm{Sr}, \mathrm{Nb}$ and $\mathrm{Ta}$ due to their potential diagenetic mobility. In contrast, the trace elements for the open ocean limestones display positive correlations with $\mathrm{MnO}(\mathrm{r}=0.45-0.70)$ but scatters or 
weak correlations with other major elements (Table S2), again pointing out their control by Mn-oxyhydroxides.

For the high-strength-field elements (HSFEs; e.g., Th, U, Sc, Zr, Hf, Ga, Na, Ta) and the transitional trace elements (e.g., $\mathrm{Co}, \mathrm{Cr}, \mathrm{Ni}, \mathrm{Cu}, \mathrm{Zn}$ ), their concentrations in the limestones are quite similar and are generally lower by one order of magnitude when compared to the PAAS (Table S1). However, the contents of the large-ion-lithophile elements (LILEs) in these limestones display obvious undulations with a large range. For example, the concentrations of $\mathrm{Sr}$ are similar to or higher by one order of magnitude than the PAAS whereas those of $\mathrm{Rb}$ and Ba vary from lower by two orders of magnitude than or similar to the PAAS (Table S1). Among the limestones deposited in various tectonic environments, the inland limestones have the lowest $\mathrm{Sr}$ contents and the open ocean limestones have the lowest $\mathrm{Rb}$ concentrations while the continental margin limestones possess the lowest Ba concentrations (Table S1), therefore the limestones from these various settings occupy distinct fields in the $\mathrm{Rb}-\mathrm{Sr}-\mathrm{Ba}$ triangular diagram (Fig. 19).

The oceanic floor limestones have the lowest contents (generally lower by more than one order of magnitude) of all the trace elements except for Sr (Table S1) because of its diagenetic mobility. Among the limestones deposited in inland and margin basins, the foreland basin limestones have the largest contents of trace ferromagnesian elements $\mathrm{Cr}, \mathrm{Co}, \mathrm{Sc}$ and V (Table S1), which could be attributed the likely terrigenous supply of ophiolitic fragments in the central Qiangtang orogen (Zhang et al., 2006a, b). However, these limestones have intermediate contents of $\mathrm{Ni}$, perhaps due to its diagenetic mobility.

\section{Geochemical proxies of sedimentary environments of limestones}


limestone biostratigraphy (e.g., Wilson, 1975), but general proxies by which

503 depositional environments of limestone can be determined are not yet available. Such

504 information will provide crucial constraints regarding the formation of sedimentary

505 basins and tectonic environments. Trace element geochemistry has been proved to be

506 a powerful tool in deciphering the plate tectonic regimes of magmatic rocks, and the

507 provenance types of siliciclastic rocks and the tectonic settings of the sedimentary

508 basins they were deposited, as well as the depositional environment of chert

509 successions (e.g., Murray et al., 1990, 1991a, 1991b, 1992; Murray, 1994; Cullers,

510 2002; Zhang, 2004; Zhang et al., 2007). Various studies have documented that trace

511 elements including REEs in carbonates tend to be relatively stable through diagenesis,

512 metamorphism or weathering (e.g., Banner et al., 1988; Holser, 1997; Webb and

513 Kamber, 2000; Nothdurft et al., 2004; Frimmel, 2009; Nagarajan et al., 2011) and

514 their patterns are a key to the average provenance compositions (Taylor and

515 McLennan, 1985; Wani and Mondal, 2010; Nagarajan et al., 2011), since REEs are

516 substituted for $\mathrm{Ca}^{2+}$ in the carbonate lattice (Zhong and Mucci, 1995) and the REE +

517 Y concentrations in diagenetic fluids are very low $\left(10^{-6}\right.$ to $\left.10^{-4} \mathrm{ppm}\right)$ (Sholkovitz et al.,

518 1989; Banner and Hanson, 1990). The limestones in this study largely display

519 subparallel patterns, indicative of weak diagenetic influences. Consequently, REEs,

520 HFSEs and other immobile elements such as $\mathrm{Al}$ are considered to be most suited for

521 tectonic setting determinations (see Murray et al., 1990; Murray, 1994).

522 REEs are most powerful tool in determining the depositional environments of the

523 limestones (e.g., Murray et al., 1990, 1991a, 1991b, 1992, 1994; Toyoda et al., 1990; 
MacLeod and Irving, 1996; Holser, 1997; Madhavaraju and Ramasamy, 1999; Madhavaraju et al., 2010, 2016). Plots between Ce/Ce*, $(\mathrm{La} / \mathrm{Yb})_{\mathrm{n}},(\mathrm{La} / \mathrm{Sm})_{\mathrm{n}}$, $(\mathrm{Sm} / \mathrm{Yb})_{\mathrm{n}}$, and $(\mathrm{La} / \mathrm{Ce})_{\mathrm{n}}$ can easily distinguish the limestones deposited in open ocean setting from those deposited in continental margins and inland lakes, those deposited in open oceanic floors from those deposited in oceanic highs (Figs. 7-9, 11, 15-18), and those deposited in passive margin from those deposited in inland and active margin environments (Fig. 9a-c). By means of characteristic high Eu anomalies of the inland freshwater limestones, they can be differentiated from the marine limestones in use of plots related to $\mathrm{Eu} / \mathrm{Eu}^{*}$ (Figs. 8b, 11). Plot of ratios of immobile ferromagnesian vs. felsic HFSEs ( $\mathrm{La} / \mathrm{Sc}$ vs. $\mathrm{Zr} / \mathrm{Ti}$ ) can also distinguish the inland freshwater limestones from the marine limestones (Fig. 20).

For the unaltered limestones of this study, LILEs can also provide useful information on the sedimentary environments that the limestones were deposited. For example, the triangular $\mathrm{Rb}-\mathrm{Sr}-\mathrm{Ba}$ diagram can well distinguish among the inland freshwater limestones, the continental marginal limestones, and the open ocean limestones (Fig. 19). In addition, the inland freshwater limestones, based on their low $\mathrm{Sr} / \mathrm{Ba}$ and $\mathrm{Sr} / \mathrm{Rb}$ ratios, are distinguished from the continental margin seawater limestones in the $\mathrm{Sr} / \mathrm{Ba}$ vs. Sr/Rb diagram (Fig. 21).

High, superchondritic Y/Ho ratios (i.e., 44-74) have been considered as a proxy for marine carbonates by previous authors, because Yttrium is not removed from seawater as efficiently as is its geochemical twin Ho (e.g., Bau, 1996). However, Johannesson et al. (2006) illustrated seawater-like REE data for ground-waters from central Mexico and proved that such signature is not unique to the marine environment. In particular, four of our Eocene Wuli freshwater limestones display superchondritic Y/Ho ratios (> 44. Fig. 5). Therefore, we do not tend to recommend 
Y/Ho ratios as proxy for marine limestones, in particular, when the limestones are impure.

\section{Tests of geochemical proxies}

We here apply the proxies presented above to 39 available literature limestone successions worldwide, ranging in age from Neoarchaean to Holocene (Table 2), to test the reliability of proxies (Fig. 22a-d). These literature successions include limestones deposited in inland freshwater basin, passive margin, active continental margins and open ocean basins, which have been well constrained by geologic and geochemical studies, and thus provide a full range of tectonic settings where limestones were deposited. Our examinations illustrate that the geochemical proxies of limestones based on immobile elemental ratios can provide reliable and useful constraints on the limestone depositional environment. For space limitation, we here exemplified the applicability of these proxies to the literature limestone suites listed in Table 2 in two diagrams about $(\mathrm{La} / \mathrm{Ce})_{\mathrm{n}}$ and Ce/Ce* ratios (Fig. 22a, b), a $\mathrm{La} / \mathrm{Sc}-\mathrm{Zr} / \mathrm{Ti}$ diagram (Fig. 22c) and a Sr/Rb-Sr/Ba diagram (Fig. 22d). Plots of these literature geochemical data in the $(\mathrm{La} / \mathrm{Ce})_{\mathrm{n}}-\mathrm{Ce} / \mathrm{Ce}^{*}$ diagrams easily distinguish the margins+inland limestones from the open ocean limestones; clearly, the diagrams using other REE ratios (e.g., $\left.(\mathrm{La} / \mathrm{Yb})_{\mathrm{n}},(\mathrm{La} / \mathrm{Sm})_{\mathrm{n}},(\mathrm{Sm} / \mathrm{Yb})_{\mathrm{n}}\right)$ (e.g., Figs. 9a, 9b, 16b, 16c, 17) also are reliable for such tectonic setting discrimination of various limestone suites. In addition, plots of available literature data in the $\mathrm{La} / \mathrm{Sc}-\mathrm{Zr} / \mathrm{Ti}$ diagram can differentiate the seawater margins limestones from the freshwater inland limestones (Fig. 22c). However, plots of literature data in the $\mathrm{Sr} / \mathrm{Rb}-\mathrm{Sr} / \mathrm{Ba}$ diagram (Fig. 22d) produce large uncertainty; for example, plots of literature geochemical data of Precambrian passive margin pure limestones (e.g., Klein and Beukes, 1989; Bolhar and 
Van Kranendonk, 2007; Nagarajan et al., 2011; Sen and Mishra, 2015) generally fall in the inland freshwater limestone area (unshown) and those of Phanerozoic margins impure limestones (e.g., Cullers, 2002; Abedini and Calagari, 2015; Madhavaraju et al., 2016) fall across the inland-margins limestone areas, although some of Phanerozoic margins pure limestones (e.g., Cullers, 2002; El Hefnawi et al., 2010; Madhavaraju et al., 2016) fall in the right area (Fig. 22d). Consequently, the proxies using LILEs should be used with great caution.

Because the proxies are principally established based upon the immobile elemental ratios, applications to the impure limestones with high non- $\mathrm{CaCO}_{3}$ composition up to $40 \mathrm{wt}$ \% (Table 2) demonstrates the validity of discrimination for tectonic environment (Fig. 22a-c). This is illustrated by the similar outcomes of discrimination utilizing impure limestones and pure limestones deposited in the Late Cretaceous active continental margin of western America (Ft. Hays, Colorado; Cullers, 2002), in the Neoproterozoic passive margin of southern India (Bhima Basin, Karnataka; Nagarajan et al., 2011), in the Aptian-Albian active continental margin (back-arc basin?) of western Mexico (Madhavaraju et al., 2010), in the Early Cretaceous Baja California fore-arc basin of Mexico (Madhavaraju et al., 2016), in the Paleoproterozoic passive margin of South Africa (Tsikos et al., 2001) and so on (Fig. 22a-c).

We note that these immobile elemental geochemical proxies also are applicable to dolomitized limestones and dolostones (Fig. 22a-c). For example, the Early Proterozoic dolostones from the northern margin of the North China craton display nearly no Ce anomalies, which, along with low $(\mathrm{La} / \mathrm{Ce})_{\mathrm{n}}$ ratios $(0.7-0.8) \quad$ (Tang et al., 2009), affirms a continental margin environment for their accumulation (Fig. 22a, b). In contrast, most of the Ediacaran-Cambrian dolostones from Oman have REE 
continental margin signatures of slightly negative $\mathrm{Ce}$ anomalies and low $(\mathrm{La} / \mathrm{Ce})_{n}$ ratioother (Fig. 22a, b. Schroder and Grotzinger, 2007), consistent with the conclusions drawn based on geologic and geochemical studies (Schroder and Grotzinger, 2007).

In addition, the geochemical proxies of immobile elemental ratios even can apply to the marbles formed at various metamorphic grades (Fig. 22a-c). For example, the granulite-facies marble from the Lower Proterozoic Hapschan Series, eastern Anabar Shield, Siberia, has $\mathrm{Ce} / \mathrm{Ce} *$ and $(\mathrm{La} / \mathrm{Ce})_{\mathrm{n}}$ ratios of $0.75-1$ and $1.02-1.64$, respectively $\left(\mathrm{Ce}^{*}\right.$ obtained by linear interpolation between shale-normalized La and Sm values, in view of absence of $\mathrm{Sm}$ values). Its protolith likely accumulated in a continental margin environment based on the limestone geochemical proxies (Fig. 22a-c), consistent with the inference from extensive studies of geology, geochemistry and isotopes (Condie et al., 1991). Even in the well-known Dabie and Sulu UHP belts, the eclogite-facies marbles display distinct REE continental margin signatures (Fig. 22a, b), compatible with the verdict based on studies of regional geology (Tang et al., 2006; Xia et al., 2012).

Application of the criteria presented above to the limestone successions whose depositional environments are under debate are particularly useful and can shed new light on the depositional setting of these special successions. For example, there is intense debate on depositional setting of stromatolitic carbonates of the Neoarchaean Fortescue Group, Pilbara Craton, western Australia, and interpretations are contrasted by lacustrine (e.g., Bolhar and Van Kranendonk, 2007) vs shallow-marine settings (e.g., Sakurai et al., 2005). This is a key issue to better understanding what geological factors controlled suitable habitats for early life (Bolhar and Van Kranendonk, 2007). Application of our immobile elemental geochemical proxies to the Pilbara carbonate 
dataset of Bolhar and Van Kranendonk (2007) points to an inland, lacustrine sedimentary environment for the Neoarchaean stromatolitic carbonates (Fig. 22a-c); in particular, they are of high $\mathrm{Zr} / \mathrm{Ti}$ ratios (Fig. 22c), consistent with a freshwater basin setting. Another example is taken from the South China block. It has been intensely debated whether there is Paleo-Tethyan branch within the South China block (e.g., Hsü, et al., 1990; Zhang and Cai, 2009). The geochemistry of the Mid-Late Permian Laibin limestones within the South China block provides further information towards resolving their depositional environment and South China tectonics. According to the dataset provided by Qiu et al. (2013), the limestones display low $\mathrm{Ce} / \mathrm{Ce} *$ values (prevalently $<0.4)$ but high $(\mathrm{La} / \mathrm{Ce})_{\mathrm{n}}$ ratios $(>4)$, indicative of an open ocean depositional environment (Fig. 22a, b). This inference is consistent with their deep-water characteristics that are revealed by abundant radiolarian fossils in the limestones (Qiu and Wang, 2010) and interbedded cherts of hydrothermal origin with distinct open ocean geochemical signatures (Qiu and Wang, 2011). Therefore, the possibility of a Paleo-Tethyan branch within the South China block cannot be overlooked.

In view that only post-mid-Mesozoic limestones are used for the establishment of the geochemical proxies in this study, special attention is paid to examine applicability of the criteria for Paleozoic and older limestones (Table 2). Such test is important since a major shift occurred in limestone sedimentation from the platforms in Proterozoic, Paleozoic and Early Mesozoic time to the open oceans by Late Mesozoic through to modern times (e.g., Arvidson et al., 2006; Ries et al., 2010) with the advent of calcareous plankton (e.g. coccolithophorids). This shift may cause changes in relative sedimentation rates of platforms versus open oceans from Paleozoic to Late Mesozoic time, which might affect adsorption of REEs and minor 
elements from seawater through burial rate variation and seawater exposure times (e.g. Murray et al., 1991). In addition, the secular shifts occurred in $\mathrm{CaCO}_{3}$ mineral polymorph dominance between aragonite and calcite in the Phanerozoic (e.g., Ries et al., 2010), which could be a factor to affect the limestone geochemistry. Our examinations on 23 limestone successions of Neoarchaean through early Mesozoic time (Table 2) indicate that these proxies based on immobile elemental ratios are well applicable to such older limestone suites (Fig. 22a-c). This is perhaps because the limestone geochemistry was principally determined by the tectonic environments in which the limestones were deposited and maybe was not liable to the changes of both limestone lithofacies and $\mathrm{CaCO}_{3}$ mineral polymorphs.

\section{Average chemical compositions of limestones}

Limestones exhibit a large variation in their bulk composition. Estimates of average geochemical compositions of limestone are still lacking and, to our knowledge, only an available estimate of major and trace element compositions of the Phanerozoic marine limestone was given by Condie et al. (1991) albeit without any detail. Such estimate is essential for its implications for sedimentary environments and seawater evolution, particularly considering that a wealth of high-quality analyses of limestones (e.g., Armstrong-Altrin et al., 2003; Frimmel, 2009; Madhavaraju et al., 2010, 2016; Fu et al., 2011; Nagarajan et al., 2011; Loope et al., 2013; Qiu et al., 2013; Tian et al., 2014; Sen and Mishra, 2015) have become available in the publications in recent years. As tectonic environment is the primary control on limestone composition as discussed above, the average compositions of limestones of four main tectonic 
settings, along with some estimate of uncertainty (standard deviations), are calculated (Table 3). We also try to give a preliminary estimate of the composition of all the limestones, but this estimate should be quite rough because it is not calculated based on the voluminous ratios of the limestones deposited in various environments. Only those samples with the total detritus $<10 \mathrm{wt} . \%$ are included in the computation (Table S3). Following Murray (1994), total iron was converted to $\mathrm{Fe}_{2} \mathrm{O}_{3}$ if it was reported as $\mathrm{FeO}$ or both ferric and ferrous values were given in the literature; data below the detection limit in several cases had been incorporated into the calculations by using a value of one-half of the detection limit.

The average composition of the open oceanic limestones is characterized by lowest $\mathrm{Al}_{2} \mathrm{O}_{3}, \mathrm{Fe}_{2} \mathrm{O}_{3}$ and $\mathrm{Ce}$ concentrations but highest $\mathrm{La}$ and other REE concentrations; therefore, these limestones have most strongly negative Ce anomalies (averagely $\mathrm{Ce} / \mathrm{Ce}^{*}=0.32$ ) and most strongly positive La anomalies (averagely, $\left.(\mathrm{La} / \mathrm{Ce})_{\mathrm{n}}=6.07\right)$ (Table 3). Among the limestones deposited in the passive and active margins and inland freshwater lakes, the passive marginal limestones have obviously lower $\mathrm{Al}_{2} \mathrm{O}_{3}$ concentrations, slightly lower negative $\mathrm{Ce}$ anomalies, and slightly higher La anomalies; the inland freshwater limestones are highlighted by their high $\mathrm{Eu} / \mathrm{Eu}^{*}$ ratios (averagely 3.74). Nevertheless, these three kinds of limestones have almost indistinguishable $\mathrm{Fe}_{2} \mathrm{O}_{3}$ and REE concentrations and other REE ratios (Table 3).

\section{Conclusions}

- We have analyzed the major, trace and rare earth elements of six Tibetan 
694 limestone successions deposited in oceanic plateau, passive continental margin, 695 active continental margin (fore-arc basin, back-arc basin and foreland basin) and 696 continental inland freshwater basin to provide a data base for our initial 697 geochemical characterizations.

698 - In combination with the Deep Sea Drilling Project and Ocean Drilling Program 699 (DSDP and ODP) literature geochemical data of limestones deposited in open 700 ocean environments, we delineate the geochemical characteristics of the $701 \quad$ limestones accumulated in various plate tectonic settings. continent and the topographic elevation as well as the volcanism, that is, by the tectonic environments of the basins. The inland + margins limestones geochemically depend on the terrigenous clasts while the open ocean limestones on the hydrothermal Fe-Mn-oxyhydroxides.

- The REE ratios (i.e., $\left.(\mathrm{La} / \mathrm{Ce})_{\mathrm{n}}, \mathrm{Ce} / \mathrm{Ce}^{*}\right)$ as well as other immobile elemental ratios (e.g., $\mathrm{Zr} / \mathrm{Ti}, \mathrm{La} / \mathrm{Sc}$ ) of limestones are good proxies of all four depositional regimes. $\mathrm{Rb}-\mathrm{Sr}-\mathrm{Ba}$ triangular diagram is also useful for distinguishing the four tectonic settings. Applications of these immobile geochemical proxies to 39

711 literature limestone successions demonstrate their validity, independent of 712 diagenetic modification, metamorphism and high siliciclastic amount $(\leq 40$ wt.\%).

- The average composition of the limestones deposited in four various depositional environments are presented, and the open oceanic limestones are differentiated 


\section{Acknowledgements}

This research was supported by the National Science Foundation of China (grants

support, to Y.Z. Zhou for helpful discussion, to A.D. Miall for kind editorial handling,

and to D. Morrow and an anonymous reviewer for constructive and thoughtful review comments, which greatly improved the manuscript.

\section{References}

Abedini, A., Calagari, A.A., 2015. Rare earth element geochemistry of the Upper Permian limestone: the Kanigorgeh mining district, NW Iran. Turkish Journal of Earth Sciences 24, 365-382.

Allen, P.A., Allen, J.R., 2005. Basin analysis: principles and applications. Second Edition, Oxford, Blackwell, 549 p.

Alonso-Zarza., A.M., 2003. Palaeoenvironmental significance of palustrine carbonates and calcretes in the geological record. Earth-Science Reviews 60, 261-298.

Armstrong-Altrin, J.S., Verma, S.P., Madhavaraju, J., Lee, Y., Ramasamy, S., 2003. Geochemistry of upper Miocene Kudankulam limestones, southern India. International Geology Review 45, 16-26.

Arvidson, R.S., Collier, M., Davis, K.J., Vinson, M.D., Amonette, J.E., Luttge, A., 
2006. Magnesium inhibition of calcite dissolution kinetics. Geochimica et Cosmochimica Acta 70, 583-594.

Banner, J.L., Hanson, G.N., 1990. Calculation of simultaneous isotopic and trace element variations during water-rock interaction with applications to carbonate diagenesis. Geochimica et Cosmochimica Acta 54, 3123-3137.

Banner, J.L., Hanson, G.N., Meyers, W.J., 1988. Rare earth element and Nd isotopic variations in regionally extensive dolomites from the Burlington-Keokuk Formation (Mississippian): Implications for REE mobility during carbonate diagenesis. Journal of Sedimentary Petrology 58, 415-432.

Bau, M., 1996. Controls on the fractionation of isovalent trace elements in magmatic and aqueous systems: Evidence from $\mathrm{Y} / \mathrm{Ho}, \mathrm{Zr} / \mathrm{Hf}$, and lanthanide tetrad effect. Contributions to Mineralogy and Petrology 123, 323-333.

Bau, M., Dulski, P., 1996. Distributions of yttrium and rare-earth elements in the Penge and Kuruman iron-formation, Transvaal Supergroup, South Africa. Precambrian Research 79, 37-55.

Bau, M., Koschinsky, A., Dulski, P., Hein, J.R., 1996. Comparison of the partitioning behaviours of yttrium, rare earth elements, and titanium between hydrogenetic marine ferromanganese crusts and seawater. Geochimica et Cosmochimica Acta $60,1709-1725$.

Bellanca, A., Masetti, D., Neri, R., 1997. Rare earth elements in limestone/marlstone couplets from the Albian-Cenomanian Cismon section (Venetian region, northern Italy): assessing REE sensitivity to environmental changes. Chemical Geology 
762

Bertram, C.J., Elderfield, H., 1993. The geochemical balance of the rare earth elements and neodymium isotopes in the oceans. Geochimica et Cosmochimica Acta 57, 1957-1986.

Bhatia, M.A., Crook, K.A.W., 1986. Trace element characteristics of graywackes and tectonic setting discrimination of sedimentary basins. Contributions to Mineralogy and Petrology 92, 181-193.

Bolhar, R., Van Kranendonk, M.J., 2007. A non-marine depositional setting for the northern Fortescue Group, Pilbara Craton, inferred from trace element geochemistry of stromatolitic carbonates. Precambrian Research 155, 229-250.

Byrne, R.H., Liu, X., Schijf, J., 1996. The influence of phosphate co-precipitation on rare earth distributions in natural waters. Geochimica et Cosmochimica Acta 60, $3341-3346$.

Chen, J.B., Algeo, T.J., Zhao, L.S., Zhen, Z.Q., Cao, L., Zhang, L., Yi, Y., 2015. Diagenetic uptake of rare earth elements by bioapatite, with an example from Lower Triassic conodonts of South China. Earth-Science Reviews 149, 181-202.

Condie, K.C., Wilks, M., Rosen, D.M., Zlobin, V.L., 1991. Geochemistry of metasediments from the Precambrian Hapschan Series, eastern Anabar Shield, Siberia. Precambrian Research 50, 37-47.

Cullers, R.L., 2002. Implications of elemental concentrations for provenance, redox conditions, and metamorphic studies of shales and limestones near Pueblo, CO, USA. Chemical Geology 191, 305-327. 
De Baar, H.J.W., Schijf, J., Byrne, R.H., 1991. Solution chemistry of the rare earth elements in seawater. European Journal of Solid State Inorganic Chemistry 28, $357-373$.

Devi, K.R., Duarah, B.P., 2015. Geochemistry of Ukhrul Limestone of Assam-Arakan Subduction Basin, Manipur, Northeast India. Journal of Geological Society of India $85,367-376$.

Dickinson, W.R., Suczek, C.A., 1979. Plate tectonics and sandstone compositions. American Association of Petroleum Geologists Bulletin 63, 2164-2182.

Durr, S., 1996. Provenance of Xigaze forearc clastic rocks (Cretaceous, south Tibet). Geological Society of America Bulletin 108, 669-691.

El Hefnawi, M.A., Mashaly, A.O., Shalaby, B.N., Rashwan, M.A., 2010. Petrography and geochemistry of Eocene limestone from Khashm Al-Raqaba area, El-Galala El-Qibliya, Egypt. Carbonates Evaporites 25, 193-202

Elderfield, H., Greaves, M.J., 1982. The rare earth elements in seawater. Nature 296, 214-219.

Frimmel, H.E., 2009. Trace element distribution in Neoproterozoic carbonates as palaeoenvironmental indicator. Chemical Geology 258, 338-353.

Frisch, W., Meschede, M., Blakey, R., 2011. Plate Tectonics. Springer, p. 212.

Fu, X.G., Wang, J., Zeng, Y.H., Tan, F.W., He, J.L., 2011. Geochemistry and origin of rare earth elements (REEs) in the Shengli River oil shale, northern Tibet, China. Chemie der Erde 71, 21-30.

Gao, J.F., Lu, J.J., Lai, M.Y., Lin, Y.P., Pu, W., 2003. Analysis of trace elements in 

$39,844-850$.

Goldstein, S.J., Jacobsen, S.B., 1988. Rare earth elements in river waters. Earth and Planetary Science Letters 89, 35-47.

Holser, W.T., 1997. Evaluation of the application of rare-earth elements to paleoceanography. Palaeogeography, Palaeoclimatology, Palaeoecology 132,

Hu, X., Wang, Y.L., Schmitt, R.A., 1988. Geochemistry of sediments on the Rio Grande Rise and the redox evolution of the South Atlantic Ocean. Geochimica et Cosmochimica Acta 52, 201-209.

Johannesson, K.H., Hawkins Jr., D.L., Cortés, A., 2006. Do Archaean chemical sediments record ancient seawater rare earth element patterns? Geochimica et Cosmochimica Acta 70, 871-890.

Kamber, B.S., Webb, G.E., 2001. The geochemistry of late Archaean microbial carbonate: Implications for ocean chemistry and continental erosion history. Geochimica et Cosmochimica Acta 65, 2509-2525.

Kawabe, I., Kitahara, Y., Naito, K., 1991. Non-chondritic Yttrium/Holmium ratio and lanthanide tetrad effect observed in pre-Cenozoic limestones. Geochemical Journal 25, 31-44. 
Kerr, A.C., 2014. Oceanic plateaus, Second ed. In: Holland, H.D., Turekian, K.K. (Eds.), Treatise on Geochemistry vol. 4. Elsevier, Oxford, pp. 631-667.

Klein, C., Beukes, N.J., 1989. Geochemistry and sedimentology of a facies transition from limestone to iron-formation deposition in the Early Proterozoic Transvaal Supergroup, South Africa. Economic Geology 84, 1733-1774.

Leeder, M.R., Smith, A.B., Yin, J.X., 1988. Sedimentology and palaeoenvironmental evolution of the 1985 Lhasa to Golmud geotraverse. Philosophical Transactions of the Royal Society, London A 327, 107-143.

Liu, G., Einsele, G., 1994. Sedimentary history of the Tethyan basin in the Tibetan Himalayas. Geologische Rundschau 83, 32-61.

Liu, Y.G., Schmitt, R.A., 1984. Chemical profiles in sediment and basalt samples from deep sea drilling project Leg 74. Hole 525A, Walvis Ridge. Initial Reports DSDP 74, 713-730.

Liu, Y.G., Miah, M.R.U., Schmitt, R.A., 1988. Cerium: A chemical tracer for paleo-oceanic redox conditions. Geochimica et Cosmochimica Acta 52, $1361-1371$.

Liu, Y.G., Schmitt, R.A., 1990. Cerium anomalies in western Indian Ocean Cenozoic carbonates, LEG 115. Proceedings of the Ocean Drilling Program, Scientific Results 115, 709-714.

Loope, G.R., Kump, L.R., Arthur, M.A., 2013. Shallow water redox conditions from the Permian-Triassic boundary microbialite: The rare earth element and iodine geochemistry of carbonates from Turkey and South China. Chemical Geology 351, 
MacLeod, K.G., Irving, A.J., 1996. Correlation of cerium anomalies with indicators of paleoenvironment. Journal of Sedimentary Research 66, 948-955.

Madhavaraju, J., González-León, C.M., Lee, Y.I., Armstrong-Altrin, J.S., Reyes-Campero, L.M., 2010. Geochemistry of the Mural Formation (Aptian-Albian) of the Bisbee Group, Northern Sonora, Mexico. Cretaceous Research 31, 400-414.

Madhavaraju, J., Loser, H., Lee, Y.I., Santacruz, R.L., Pi-Puig, T., 2016. Geochemistry of Lower Cretaceous limestones of the Alisitos Formation, Baja California, Mexico: Implications for REE source and paleo-redox conditions. Journal of South American Earth Sciences 66, 149-165.

Madhavaraju, J., Ramasamy, S., 1999. Rare earth elements in limestones of Kallankurichchi Formation of Ariyalur Group, Tiruchirapalli Cretaceous, Tamil Nadu. Journal of the Geological Society of India 54, 291-301.

Mazumdar, A., Tanaka, K., Takahashi T., Kawabe, I., 2003. Characteristics of rare earth element abundances in shallow marine continental platform carbonates of Late Neoproterozoic successions from India. Geochemical Journal 37, 277-289.

Michel, H.V., Asaro, F., Alvarez, W., Alvarez, L.W., 1985. Elemental profile of iridium and other elements near the Cretaceous/Tertiary boundary in Hole 577B. Initial Reports DSDP 86, 533-538.

Murray, R.W., Buchholtz Ten Brink, M.R., Jones, D.L., Gerlach, D.C., Russ III, G.P., 1990. Rare earth element as indicators of different marine depositional 
Murray, R.W., Buchholtz Ten Brink, M.R., Gerlach, D.C., Russ III, G.P., Jones, D.L., 1991a. Rare earth, major and trace elements in chert from the Franciscan Complex and Monterey Group, California: Assessing REE sources to fine-grained marine sediments. Geochimica et Cosmochimica Acta 55, 1875-1895.

Murray, R.W., Buchholtz Ten Brink, M.R., Gerlach, D.C., Russ III, G.P., Jones, D.L., 1991b. Rare earth elements in Japan Sea sediments and diagenetic behavior of Ce/Ce*, results from ODP Leg 127. Geochimica et Cosmochimica Acta 55, 2453-2466.

Murray, R.W., Buchholtz Ten Brink, M.R., Gerlach, D.C., Russ III, G.P., Jones, D.L., 1992. Interoceanic variation in the rare earth, major, and trace element depositional chemistry of chert: Perspectives gained from the DSDP and ODP record. Geochimica et Cosmochimica Acta 56, 1897-1913.

Murray, R.W., 1994. Chemical criteria to identify the depositional environment of chert: general principles and applications. Sedimentary Geology, 90, 213-232.

Nagarajan, R., Madhavaraju, J., Armstrong-Altrin, J.S., Nagendra, R., 2011. Geochemistry of Neoproterozoic limestones of the Shahabad Formation, Bhima Basin, Karnataka, southern India. Geosciences Journal 15, 9-25.

Nath, B.N., Roelandts, I., Sudhakar, M., Plueger, W.L., 1992. Rare Earth Element patterns of the Central Indian Basin sediments related to their lithology. Geophysical Research Letters 19, 1197-1200.

Nath, B.N., Bau, M., Ramalingeswara Rao, B., Rao, C. M., 1997. Trace and rare earth 
elemental variation in Arabian Sea sediments through a transect across the oxygen minimum zone. Geochimica et Cosmochimica Acta 61, 2375-2388.

Nothdurft, L.D., Webb, G.E., Kamber, B.S., 2004. Rare earth element geochemistry of Late Devonian reefal carbonates, Canning Basin, Western Australia: confirmation of a seawater REE proxy in ancient limestones. Geochimica et Cosmochimica Acta 68, 263-283.

Qiu, Z., Wang, Q.C., 2010. Middle and Upper Permian Sedimentary microfacies in the Tieqiao section (Laibin, Guangxi, China). Acta Sedimentologica Sinica 2010, $28,1020-1036$.

Qiu, Z., Wang, Q.C., 2011. Geochemical evidence for submarine hydrothermal origin of the Middle-Upper Permian chert in Laibin of Guangxi. Science China Earth Sciences 54, 1011-1023.

Qiu, Z., Wang, Q.C., Yan, D.T., 2013. Geochemistry of the Middle to Late Permian limestones from the marginal zone of an isolated platform (Laibin, South China). Science China Earth Sciences 56, 1688-1700.

Ries, J.B., 2010. Review: geological and experimental evidence for secular variation in seawater $\mathrm{Mg} / \mathrm{Ca}$ (calcite-aragonite seas) and its effects on marine biological calcification. Biogeosciences 7, 2795-2849.

Ruhlin, D.E., Owen, R.M., 1986. The rare earth element geochemistry of hydrothermal sediments from the East Pacific Rise: Examination of a seawater scavenging mechanism. Geochimica et Cosmochimica Acta 50, 393-400.

Sakurai, R., Ito, M., Ueno, Y., Kitajima, K., Maruyama, S., 2005. Facies architecture 

Craton, northwestern Australia: implications for depositional environments of oxygenic stromatolites during the Late Archean. Precambrian Research 138,

Schroder, S., Grotzinger, J.P., 2007. Evidence for anoxia at the Ediacaran-Cambrian 920 boundary: the record of redox-sensitive trace elements and rare earth elements in Oman. Journal of the Geological Society, London 164, 175-187.

Sen, S., Mishra, M., 2015. Geochemistry of Rohtas limestone from Vindhyan Supergroup, central India: Evidences of detrital input from felsic source. Geochemistry International 53, 1107-1122.

Shields, G.A., Webb, G.E., 2004. Has the REE composition of seawater changed over geological time? Chemical Geology 204, 103-107.

Sholkovitz, E.R., Piepgras, D.J., Jacobsen, S.B., 1989. The pore water chemistry of rare elements Buzzard Bay sediments. Geochimica et Cosmochimica Acta 53, 2847-2856.

Siby, K., Nath, B.N., Ramaswamy, V., Naman, D., Gnaneshwar Rao, T. Kamesh Raju, K.A., Selvaraj, K., and Chen, C.T.A., 2008. Possible detrital, diagenetic and hydrothermal sources for Holocene sediments of the Andaman backarc basin. Marine Geology 247, 178-193.

Tang, H.S., Chen, Y.J., Wu, G., Yang, T., 2009. Rare earth element geochemistry of carbonates of Dashiqiao Formation, Liaohe Group, eastern Liaoning province: Implications for Lomagundi Event. Acta Petrologica Sinica 25, 3075-3093. 
Tang, J., Zheng, Y.F., Wu, Y.B., Gong, B., 2006. Zircon SHRIMP U-Pb dating, C and O isotopes for impure marbles from the Jiaobei terrane in the Sulu orogen: Implication for tectonic affinity. Precambrian Research 144, 1-18.

Tarduno, J.A., McWilliams, M., Debiche, M.G., Sliter, W.V., Blake Jr., M.C., 1985. Franciscan Complex Calera limestones: Accreted remnants of Farallon Plate oceanic plateau. Nature $317,345-347$.

Taylor, S.R., McLennan, S.M., 1985. The Continental Crust: Its Composition and Evolution. Blackwell, Cambridge, p. 312.

Tian, Y., Zhao, X.M., Wang, L.Z., Tu, B., Xie, G.G., Zeng, B.F., 2014. Geochemical characteristics and its paleoenvironmental implication of Permian Qixia Formation in Shizhu, Chongqing. Acta Sedimentologica Sinica 32, 1035-045.

Tlig, S., M'Rabet, A., 1985. A comparative study of the Rare Earth Element (REE) distributions within the lower Cretaceous dolomites and limestones of Central Tunisia. Sedimentology 32, 897-907.

Toyoda, K., Nakamura, Y., Masuda, A., 1990. Rare earth elements of Pacific pelagic sediments. Geochimica et Cosmochimica Acta 54, 1093-1103.

Tsikos, H. Moore, J.S., Harris, C., 2001. Geochemistry of the Palaeoproterozoic Mooidraai Formation: Fe-rich limestone as end member of iron formation deposition, Kalahari Manganese Field, Transvaal Supergroup, South Africa. Journal of African Earth Sciences 32, 19-27.

Van Kranendonk, M.J., Webb, G.E., Kamber, B.S., 2003. New geological and trace element evidence from $3.45 \mathrm{Ga}$ stromatolitic carbonates in the Pilbara Craton: 

Geobiology 1, 91-108.

961

962

963

964

965

966

967

968

969

970

971

972

973

974

975

976

977

978

979

980

Wang, C.S., Zhao, X.X., Liu, Z.F., Lippert, P.C., Graham, S.A., Coe, R.S., Yi, H.S., Zhu, L.D., Liu, S., Li, Y.L., 2008. Constraints on the early uplift history of the Tibetan Plateau. Proceedings of the National Academy of Sciences of the United States of America 105, 4987-4992.

Wang, L., Wang, X.Q., Li, J., 1999. Qiabulin formation stratigraphy and analysis of tectonic setting in Xigaze, Tibet. Geoscience 13, 281-286.

Wang, Y.L., Liu, Y.G., Schmitt, R.A., 1986. Rare earth element geochemistry of south Atlantic deep sediments, Ce anomaly change at $\sim 54$ My. Geochimica et Cosmochimica Acta 50, 1337-1355.

Wani, H., Mondal, M.E.A., 2010. Petrological and geochemical evidence of the Paleoproterozoic and the Meso-Neoproterozoic sedimentary rocks of the Bastar craton, Indian Peninsula: Implications on paleoweathering and Proterozoic crustal evolution. Journal of Asian Earth Sciences 38, 220-232.

Webb, G.E., Kamber, B.S., 2000. Rare earth elements in Holocene reefal microbialites: a new shallow seawater proxy. Geochimica et Cosmochimica Acta 64, $1557-1565$.

Wilson, J.L., 1975. Carbonate Facies in Geologic History. Springer-Verlag, p. 471.

Xia, B., Yuan, Y.J., Zhang, Y.Q., Wang, M., Xia, L.Z., Li, H., Wang, F.Y., Zhang, H., Wu, W.P., 2012. Zircon U-Pb ages of marble from Shuanghe, Qianshan County and their geological significance. Acta Geologica Sinica 86, 619-625. 
981

982

983

984

985

986

987

988

989

990

991

992

993

994

995

996

997

998

999

1000

1001

1002

XZBGM (Xizang Bureau of Geology and Mineral Resources), 1993. Regional Geology of Xizang Autonomous Region, China. Beijing, Geological Publishing House, p. 707.

Zhang, K.J., 2000. Cretaceous paleogeography of Tibet and adjacent areas (China): Tectonic implications. Cretaceous Research 21, 23-33.

Zhang, K.J., 2004. Secular geochemical variations of the Lower Cretaceous siliciclastic rocks from central Tibet (China) indicate a tectonic transition from continental collision to back-arc rifting. Earth and Planetary Science Letters 229, 73-89.

Zhang, K.J., Cai, J.X., 2009. NE-trending Hepu-Hetai dextral shear zone in southern China: Penetration of the Yunkai Promontory of South China into Indochina. Journal of Structural Geology 31, 737-748.

Zhang, K.J., Xia, B.D., Liang, X.W., 2002. Mesozoic-Paleogene sedimentary facies and paleogeography of Tibet, western China: Tectonic implications. Geological Journal 37, 217-246.

Zhang, K.J., Xia, B.D., Wang, G.M., Li, Y.T., Ye, H.F., 2004. Early Cretaceous stratigraphy, depositional environment, sandstone provenance, and tectonic setting of central Tibet, western China. Geological Society of America Bulletin 116, 1202-1222.

Zhang, K.J., Cai, J.X., Zhang, Y.X., Zhao, T.P., 2006a. Eclogites from central Qiangtang, northern Tibet (China) and tectonic implications. Earth and Planetary Science Letters 245, 722-729. 
Zhang, K.J., Zhang, Y.X., Xia, B.D., He, Y.B., 2006b. Temporal variations of the Mesozoic sandstone composition in the Qiangtang block, northern Tibet (China): Implications for provenance and tectonic setting. Journal of Sedimentary Research $76,1035-1048$.

Zhang, K.J., Zhang, Y.X., Li, B., Zhong, L.F., 2007. Nd isotopes of siliciclastic rocks from Tibet, western China: Constraints on the pre-Cenozoic tectonic evolution. Earth and Planetary Science Letters 256, 604-616.

Zhang, K.J., Zhang, Y.X., Tang, X.C., Xia, B., 2012. Late Mesozoic tectonic evolution and growth of the Tibetan plateau prior to the Indo-Asian collision. Earth-Science Reviews 114, 236-249.

Zhang, K.J., Xia, B., Zhang, Y.X., Liu, W.L., Zeng, L., Li, J.F., Xu, L.F., 2014. Central Tibetan Meso-Tethyan oceanic plateau. Lithos 210-211, 278-288.

Zhao, H.W., Jones, B., 2013. Distribution and interpretation of rare earth elements and yttrium in Cenozoic dolostones and limestones on Cayman Brac, British West Indies. Sedimentary Geology 284-285, 26-38.

Zhong, S., Mucci, A., 1995. Partitioning of rare earth elements (REEs) between calcite and seawater solutions at $25^{\circ} \mathrm{C}$ and 1 atm, and high dissolved REE concentrations. Geochimica et Cosmochimica Acta 59, 443-453.

\section{Figure and Table Captions}

Fig. 1. (A) Schematic global plate tectonic map, reproduced from the General Bathymetric Chart of the Oceans world map 2014 (www.gebco.net), showing the 
open oceanic sites referenced in this study. The characters in parentheses denote the references: H-Hu et al., 1988; L1-Liu et al., 1988; L2-Liu and Schmitt, 1984; L3-Liu and Schmitt, 1990; M-Michel et al., 1985. (B) Schematic tectonic map of Tibet, western China (after Zhang et al., 2012), showing the sampling sites in this study. Age abbreviations: T-Tertiary; K2-Late Cretaceous; K1-Early Cretaceous; J2-Middle Jurassic.

Fig. 2. Positive correlations of $\mathrm{Al}_{2} \mathrm{O}_{3}$ with $\mathrm{Fe}_{2} \mathrm{O}_{3}$ and $\mathrm{MnO}$ of the limestones deposited in open ocean environments of the Pacific, Atlantic, and Indian Oceans, central Tibetan Meso-Tethyan oceanic plateau and Tibetan inland and continental margin environments. Data plotted are listed in Table S1. For the sample locations, see Fig. 1a and b. Data sources: Pacific Ocean floor-Liu et al., 1988; Indian Ocean floor-Liu and Schmitt, 1990; Rgr-Hu et al., 1988; Stsk-Michel et al., 1985; Wlv-Liu and Schmitt, 1984; the others are from this study.

Fig. 3. REE $+Y$ concentrations of limestones deposited in open ocean environments of the Pacific, Atlantic, and Indian Oceans and central Tibetan Meso-Tethyan oceanic plateau, normalized to PAAS (Taylor and McLennan, 1985). Data plotted are listed in Table S1. For the sample locations, see Fig. 1a and b. Data sources: Pacific Ocean floor-Liu et al., 1988; Indian Ocean floor-Liu and Schmitt, 1990; Rio Grande Rise-Hu et al., 1988; Walvis Ridge-Liu and Schmitt, 1984; Shatsky Rise-Michel et al., 1985; Meso-Tethyan ocean plateau (GZ in Fig. 1b)-this 
study.

Fig. 4. REE+Y concentrations of limestones deposited in continental margin environments, Tibet, western China, normalized to PAAS (Taylor and McLennan, and are from this study.

Fig. 5. REE $+Y$ concentrations of limestones deposited in inland freshwater environment, Tibet, western China, normalized to PAAS (Taylor and McLennan, 1985). For the sample locations, see Fig. 1b. Data plotted are listed in Table S1 and are from this study.

Fig. 6. $\mathrm{La}$ vs. $\mathrm{Al}_{2} \mathrm{O}_{3}, \mathrm{Fe}_{2} \mathrm{O}_{3}, \mathrm{MnO}$ and $\mathrm{P}_{2} \mathrm{O}_{5}$ of limestones deposited in various depositional environments. Data plotted are listed in Table S1. For the sample locations, see Fig. 1a and b. Data sources: Pacific Ocean floor-Liu et al., 1988; Indian Ocean floor-Liu and Schmitt, 1990; Rgr-Hu et al., 1988; Stsk-Michel et al., 1985; Wlv-Liu and Schmitt, 1984; the others are from this study.

Fig. 7. $\mathrm{Ce} / \mathrm{Ce}^{*}$ vs. $\mathrm{Al}_{2} \mathrm{O}_{3}, \mathrm{Fe}_{2} \mathrm{O}_{3}, \mathrm{MnO}$ and $\mathrm{P}_{2} \mathrm{O}_{5}$ of limestones deposited in various depositional environments. $\mathrm{Ce} / \mathrm{Ce}^{*}$ is normalized to PAAS (Taylor and McLennan, 1985). Data plotted are listed in Table S1. Data sources as in Fig. 6. 
Fig. 8. $\Sigma \mathrm{REE} / \mathrm{Al}$ vs. $\mathrm{Ce} / \mathrm{Ce}^{*}$ and $\mathrm{Eu} / \mathrm{Eu}^{*}$ of limestones deposited in various depositional environments, normalized to PAAS (Taylor and McLennan, 1985). Data plotted are listed in Table S1. Data sources as in Fig. 6.

Fig. 9. $\mathrm{Ce} / \mathrm{Ce}^{*}$ vs. $(\mathrm{La} / \mathrm{Yb})_{\mathrm{n}},(\mathrm{La} / \mathrm{Sm})_{\mathrm{n}},(\mathrm{Sm} / \mathrm{Yb})_{\mathrm{n}}$ and $(\mathrm{La} / \mathrm{Ce})_{\mathrm{n}}$ of limestones deposited in various depositional environments, normalized to PAAS (Taylor and McLennan, 1985). Data plotted are listed in Table S1. Data sources as in Fig. 6.

Fig. 10. $\mathrm{Eu} / \mathrm{Eu}^{*}$ vs. $\mathrm{Al}_{2} \mathrm{O}_{3}, \mathrm{Fe}_{2} \mathrm{O}_{3}, \mathrm{MnO}$ and $\mathrm{P}_{2} \mathrm{O}_{5}$ of limestones deposited in various depositional environments, $\mathrm{Eu} / \mathrm{Eu}^{*}$ is normalized to PAAS (Taylor and McLennan, 1985). Data plotted are listed in Table S1. Data sources as in Fig. 6.

Fig. 11. $\mathrm{Eu} / \mathrm{Eu}^{*}$ vs. $\mathrm{Ce} / \mathrm{Ce}^{*}$ of limestones deposited in various depositional environments, normalized to PAAS (Taylor and McLennan, 1985). Data plotted are listed in Table S1. Data sources as in Fig. 6.

Fig. 12. $\mathrm{Al}_{2} \mathrm{O}_{3}$ vs. $(\mathrm{La} / \mathrm{Sm})_{\mathrm{n}},(\mathrm{Sm} / \mathrm{Yb})_{\mathrm{n}}$, and $(\mathrm{La} / \mathrm{Yb})_{\mathrm{n}}$ of limestones deposited in various depositional environments, normalized to PAAS (Taylor and McLennan, 1985). Data plotted are listed in Table S1. Data sources as in Fig. 6.

Fig. 13. $\mathrm{Fe}_{2} \mathrm{O}_{3}$ vs. $(\mathrm{La} / \mathrm{Sm})_{\mathrm{n}},(\mathrm{Sm} / \mathrm{Yb})_{\mathrm{n}}$, and $(\mathrm{La} / \mathrm{Yb})_{\mathrm{n}}$ of limestones deposited in various depositional environments, normalized to PAAS (Taylor and McLennan, 
Fig. 14. $\mathrm{MnO}$ vs. $(\mathrm{La} / \mathrm{Sm})_{\mathrm{n}},(\mathrm{Sm} / \mathrm{Yb})_{\mathrm{n}}$, and $(\mathrm{La} / \mathrm{Yb})_{\mathrm{n}}$ of limestones deposited in various depositional environments, normalized to PAAS (Taylor and McLennan, 1985). Data plotted are listed in Table S1. Data sources as in Fig. 6.

Fig. 15. $\mathrm{Al}_{2} \mathrm{O}_{3} /\left(\mathrm{Al}_{2} \mathrm{O}_{3}+\mathrm{Fe}_{2} \mathrm{O}_{3}\right)$ vs. $(\mathrm{La} / \mathrm{Ce})_{\mathrm{n}}$ of limestones deposited in various depositional environments, normalized to PAAS (Taylor and McLennan, 1985). Data plotted are listed in Table S1. Data sources as in Fig. 6.

Fig. 16. $(\mathrm{La} / \mathrm{Ce})_{\mathrm{n}}$ vs. $(\mathrm{La} / \mathrm{Sm})_{\mathrm{n}},(\mathrm{Sm} / \mathrm{Yb})_{\mathrm{n}}$, and $(\mathrm{La} / \mathrm{Yb})_{\mathrm{n}}$ of limestones deposited in various depositional environments, normalized to PAAS (Taylor and McLennan, 1985). Data plotted are listed in Table S1. Data sources as in Fig. 6.

Fig. 17. $(\mathrm{La} / \mathrm{Yb})_{\mathrm{n}}$ vs. $(\mathrm{La} / \mathrm{Sm})_{\mathrm{n}}$ vs. $(\mathrm{Sm} / \mathrm{Yb})_{\mathrm{n}}$ of limestones deposited in various depositional environments, normalized to PAAS (Taylor and McLennan, 1985). Data plotted are listed in Table S1. Data sources as in Fig. 6.

Fig. 18. $\Sigma \mathrm{REE} / \mathrm{Al}$ vs. $(\mathrm{La} / \mathrm{Sm})_{\mathrm{n}},(\mathrm{Sm} / \mathrm{Yb})_{\mathrm{n}}$, and $(\mathrm{La} / \mathrm{Yb})_{\mathrm{n}}$ of limestones deposited in various depositional environments, normalized to PAAS (Taylor and McLennan, 1985). Data plotted are listed in Table S1. Data sources as in Fig. 6. 
1113

1114

1115

1116

1117

1118

1119

1120

1121

1122

1123

1124

1125

1126

Fig. 19. $\mathrm{Rb}-\mathrm{Sr}-\mathrm{Ba}$ triangular diagram of limestones deposited in various depositional environments. Data plotted are listed in Table S1. Data sources as in Fig. 6.

Fig. 20. $\mathrm{Zr} / \mathrm{Ti}$ vs. $\mathrm{La} / \mathrm{Sc}$ of Tibetan limestones deposited in inland freshwater basin and continental margin environments. Data plotted are listed in Table S1 and are from this study.

Fig. 21. $\mathrm{Sr} / \mathrm{Ba}$ vs. $\mathrm{Sr} / \mathrm{Rb}$ diagram of Tibetan limestones deposited in inland freshwater basin and continental margin environments. Data plotted are listed in Table S1 and are from this study.

Fig. 22. Tests of geochemical proxies for the plate tectonic settings in which the limestones were deposited. (a) is from Fig. 16a, (b) from Fig. 9c, (c) from Fig. 20 and (d) from Fig. 21. The numbers in these diagrams represent the same serial numbers of literature limestone sites as listed in Table 2; Nos. 1-6, active continental margin; Nos. 7-23, passive continental margin; Nos. 24-26, open ocean; Nos. 27-29, inland; No. 30-under debate; Nos. 31-36, dolostone; Nos. 37-39, marble; Nos. 1-7, 9, 14, 18, 20, 22, and 30 contain impure limestones (non- $\mathrm{CaCO}_{3}>10 \mathrm{wt} . \%$ ). See Table 2 for the details about the age, tectonic setting and data sources of these limestone suites. The yellow and white areas in (d) denote the impure and pure limestones, respectively. 
1135 Table 1. Plate tectonic classification of basins in which limestones deposited.

1136

1137 Table 2. Tectonic setting classification of various limestone suites for test of 1138 geochemical proxies.

1139

1140 Table 3. Average geochemical compositions of limestones deposited in various 1141 tectonic environments.

1142 

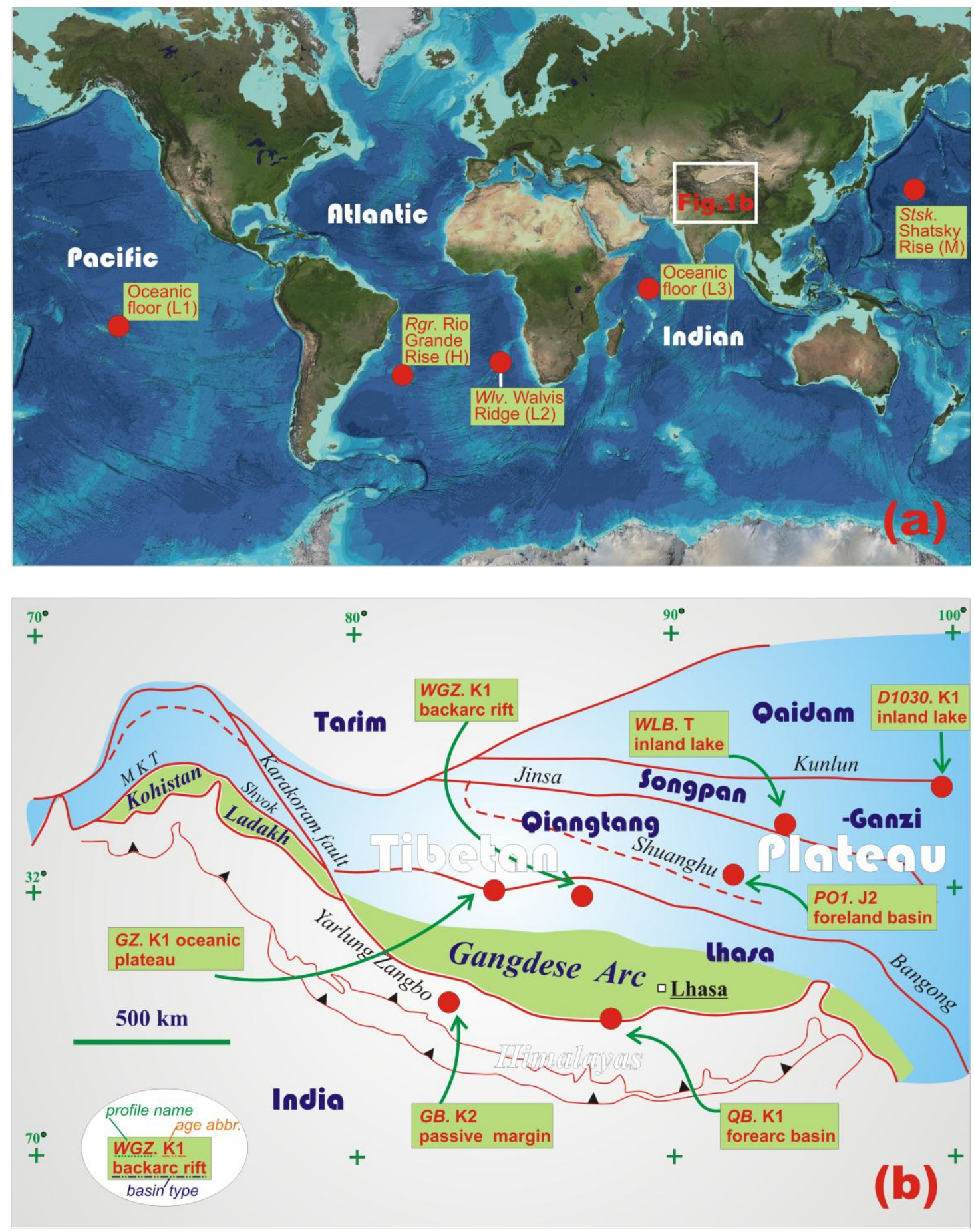

1144 

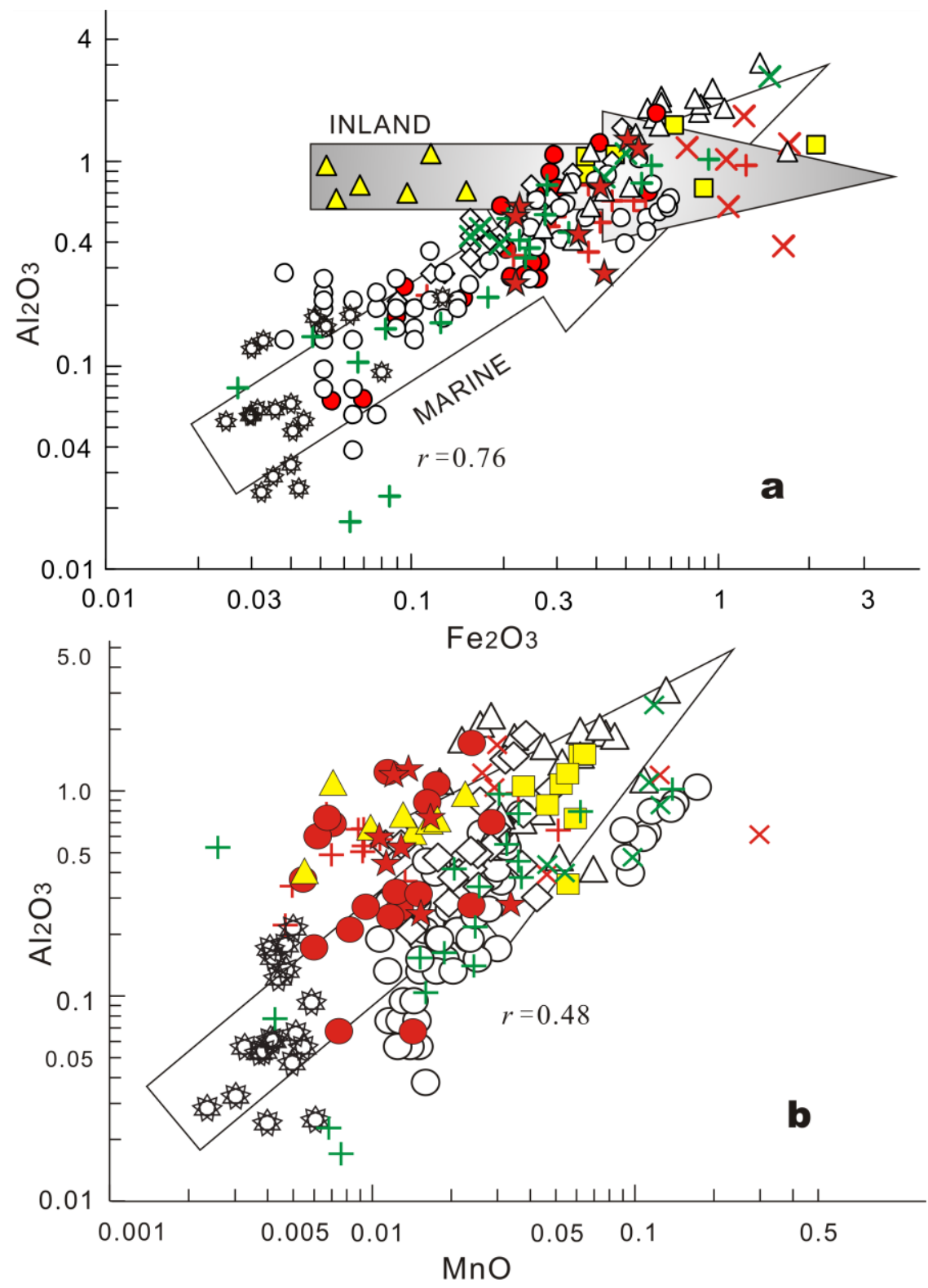

open ocean margins

floors X Pacific + Indian backarc $\downarrow$ WGZ forearc $O \mathrm{QB}$ highs Gz $\diamond$ Wlv O Stsk $\triangle$ Rgr foreland $X \mathrm{PO} 1$ passive $+\mathrm{GB}$

$1145 \quad$ inland $\triangle \mathrm{D} 1030 \square \mathrm{WLB}$

1146 


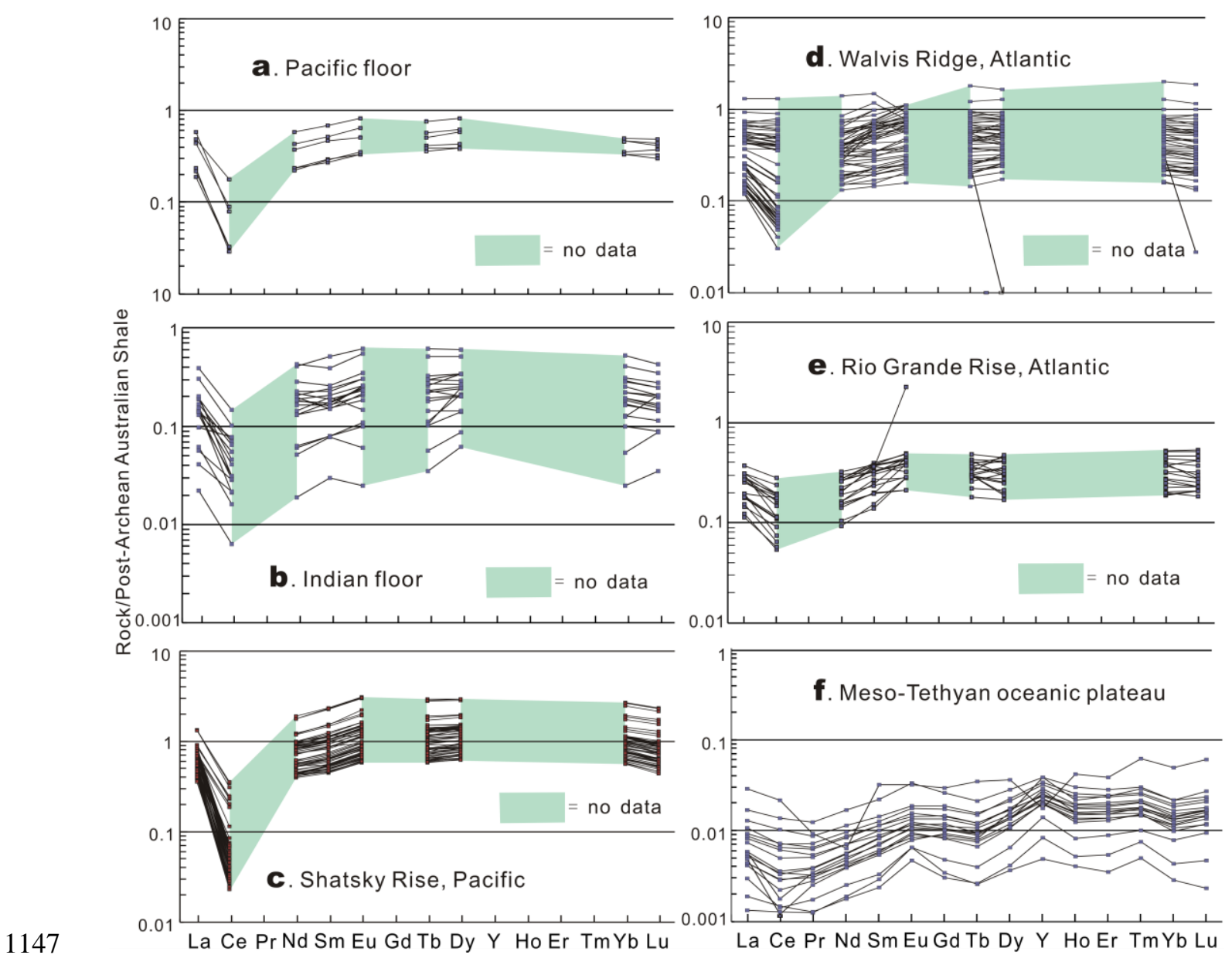

1148 

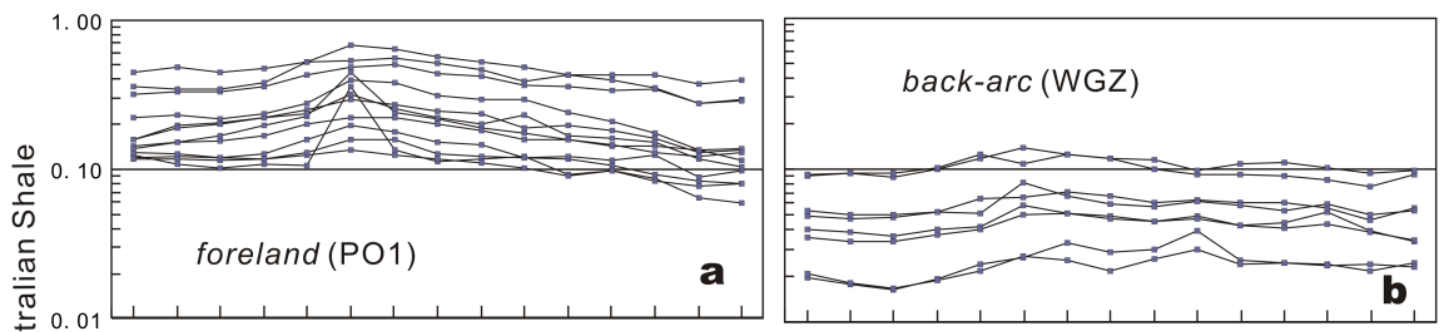

1149
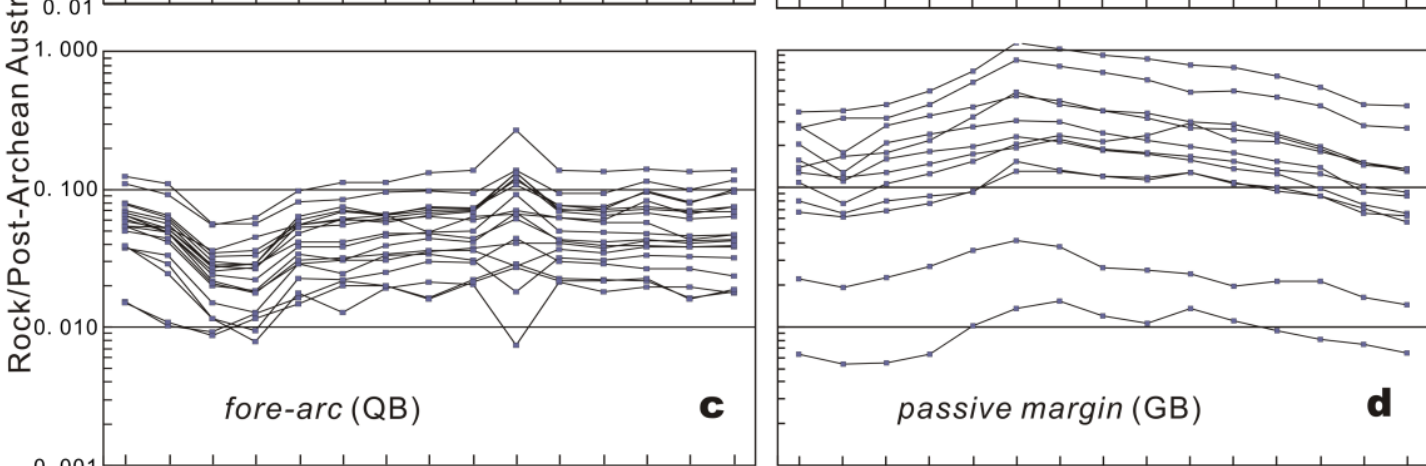
La Ce Pr Nd SmEu Gd Tb Dy Y Ho Er Tm Yb Lu La Ce Pr Nd SmEu Gd Tb Dy Y Ho Er Tm Yb Lu

1150 


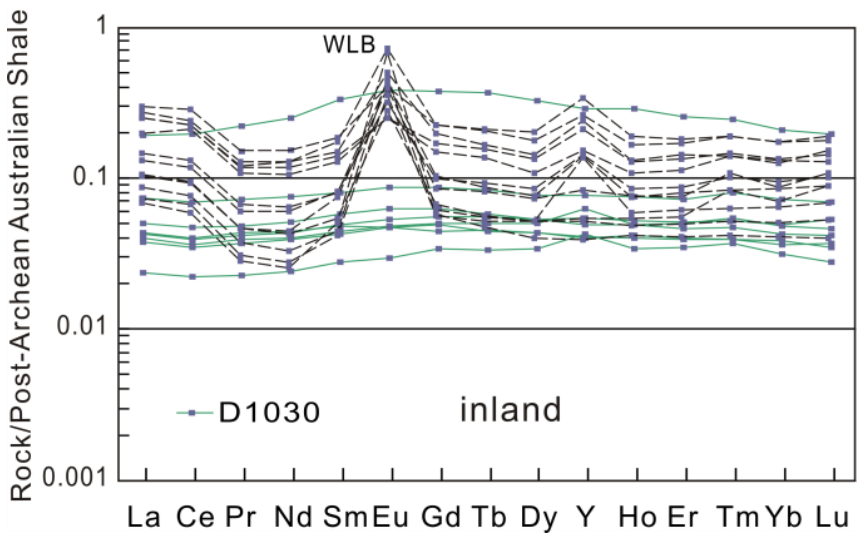

1152 

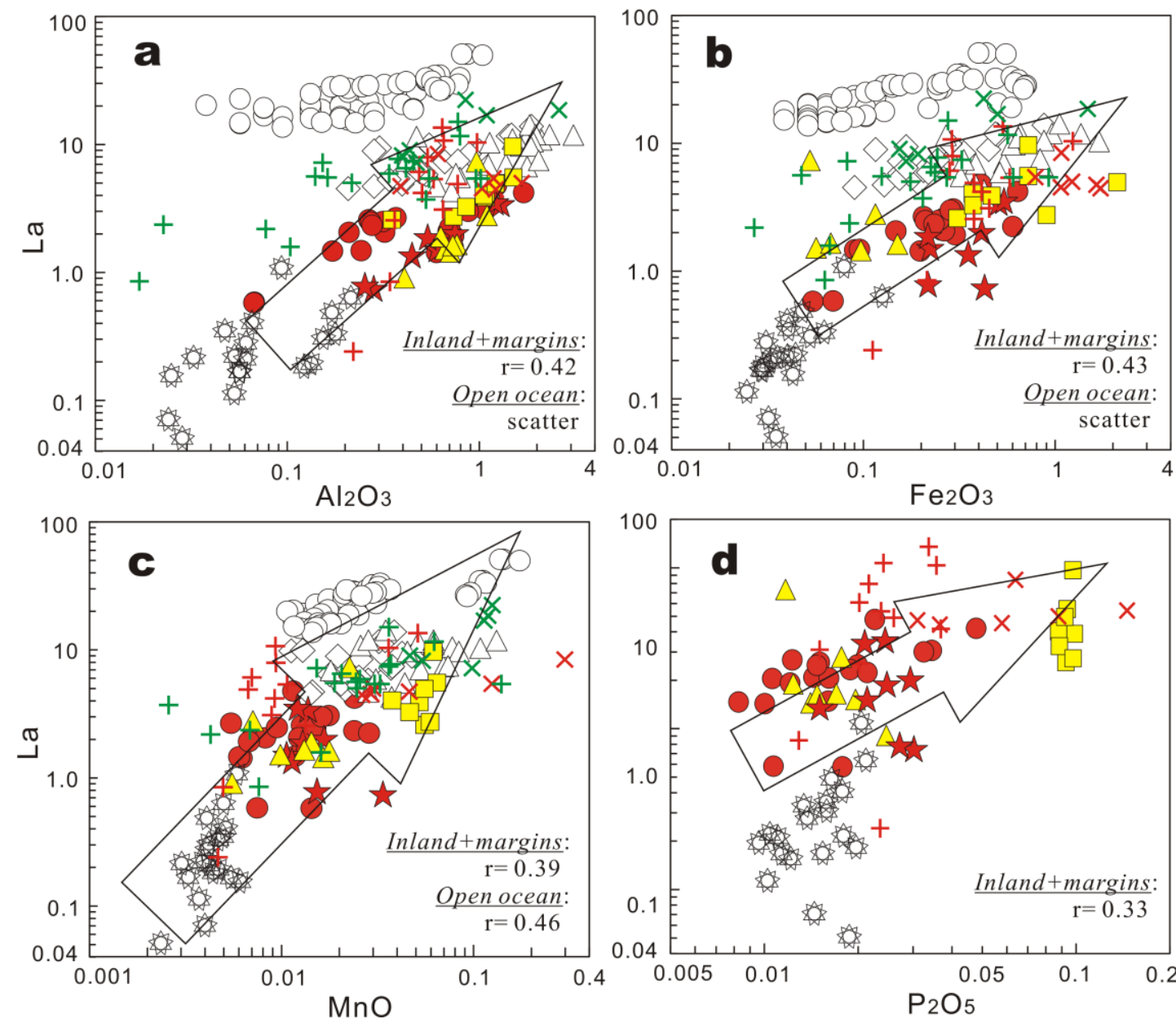

open ocean

margins

inland

floors $\times$ Pacific +Indian backarc $\star$ WGZ forearc O QB $\triangle$ D1030

1153

highs GZ $\diamond$ WIv O Stsk $\triangle$ Rgr foreland XPO1 passive + GB $\square$ WLB

1154 

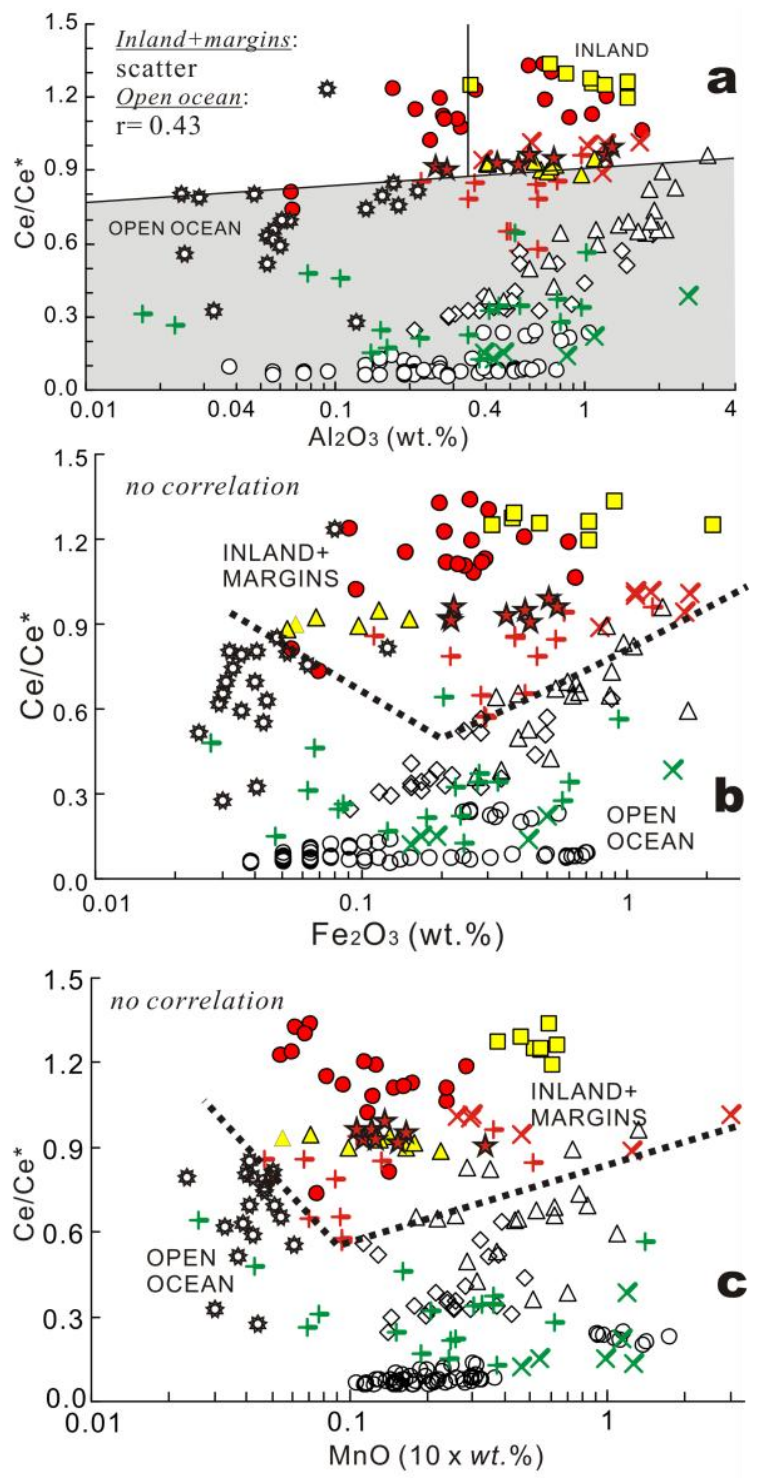

open ocean

floors XPacific + Indian

highs GZ $\diamond W l v O$ Stsk $\triangle$ Rgr

inland $\triangle$ D1030 $\square$ WLB

margins

backarc $\downarrow$ WGZ forearc $\bigcirc \mathrm{QB}$

1155

foreland XPo1 passive $+\mathrm{GB}$ 

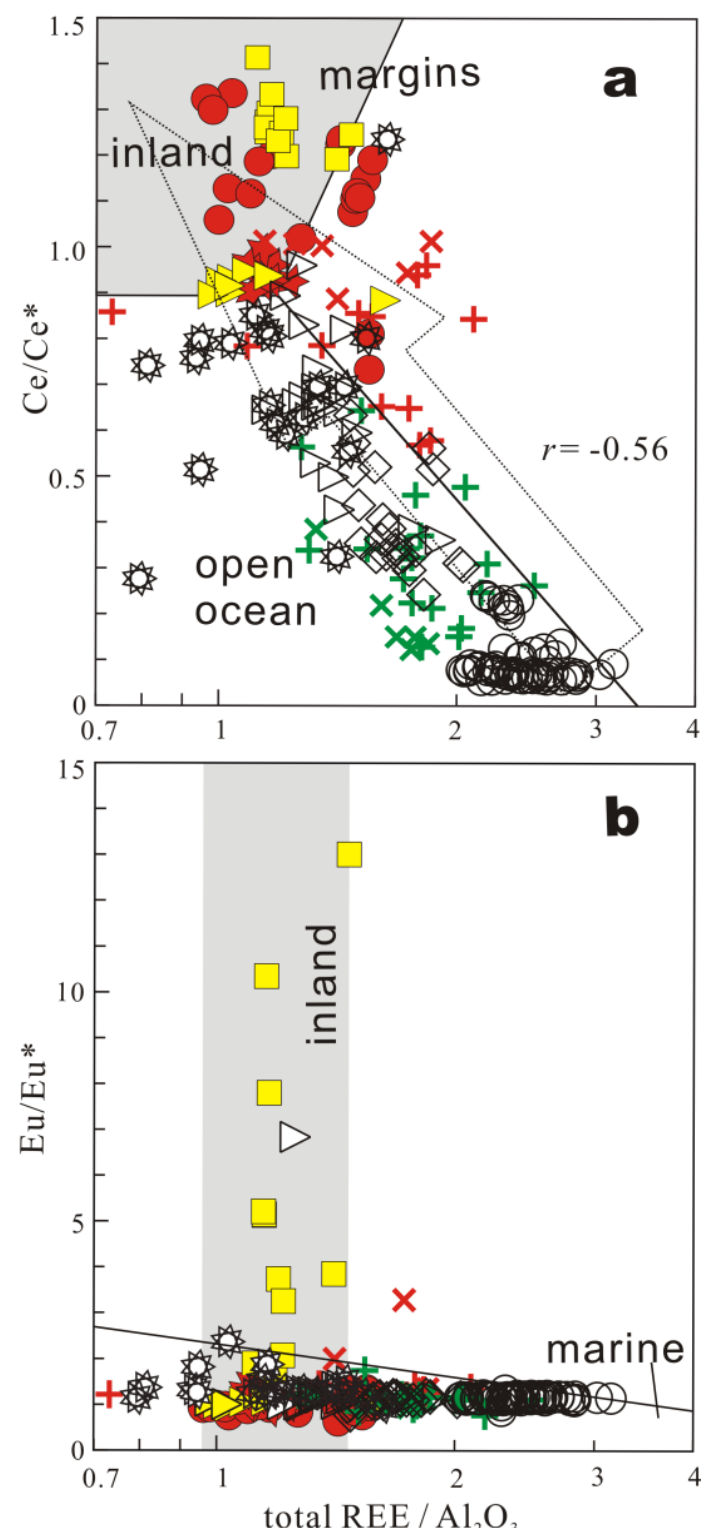

open ocean

floors $\times$ Pacific +Indian

highs GZ $\diamond$ WIv OStsk $\triangleright$ Rgr inland $\triangle$ D1030 $\square$ WLB

margins

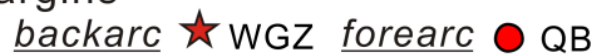

1157

foreland X PO1 passive $+\mathrm{GB}$

1158 

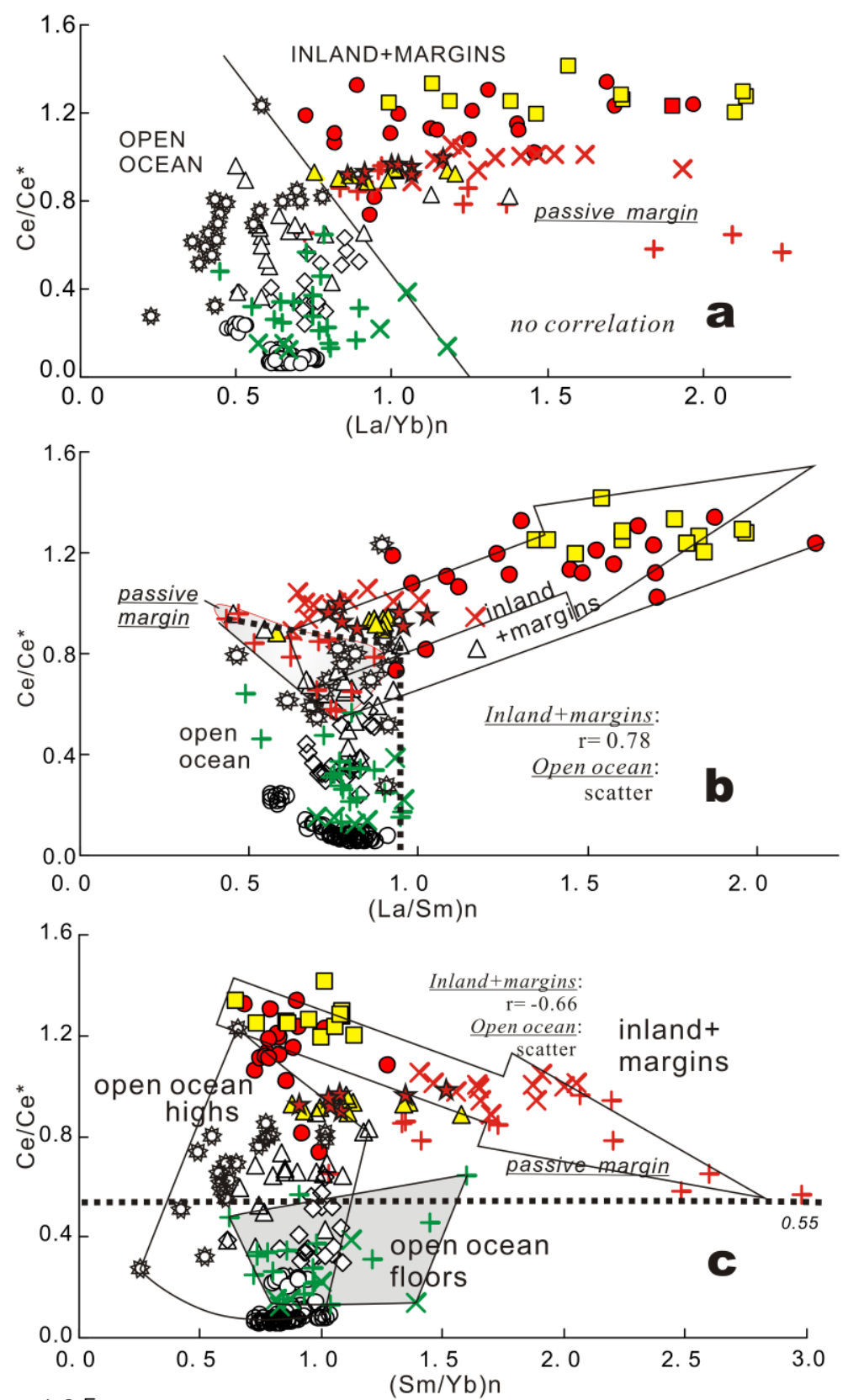

1159

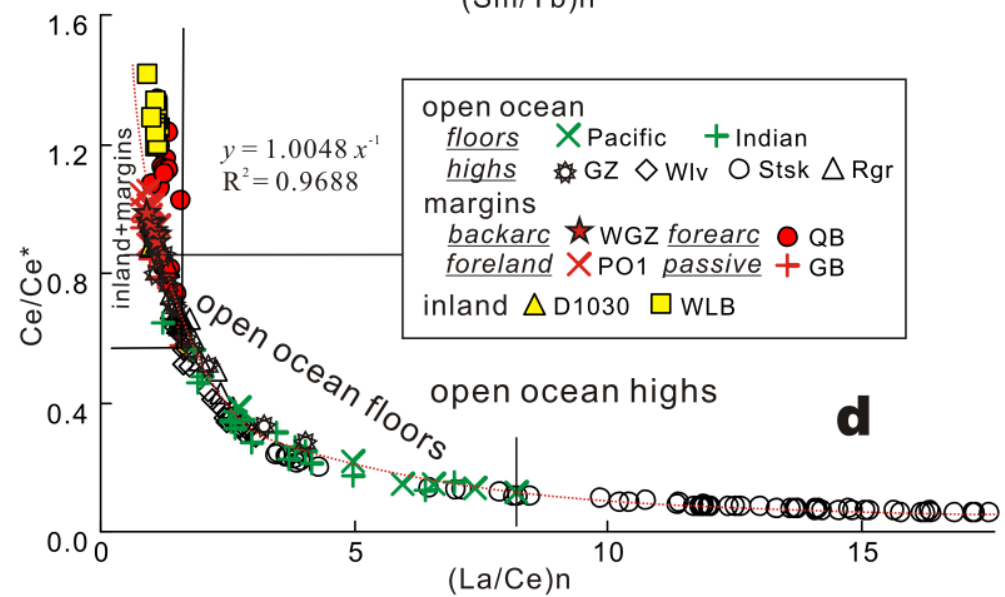

1160 

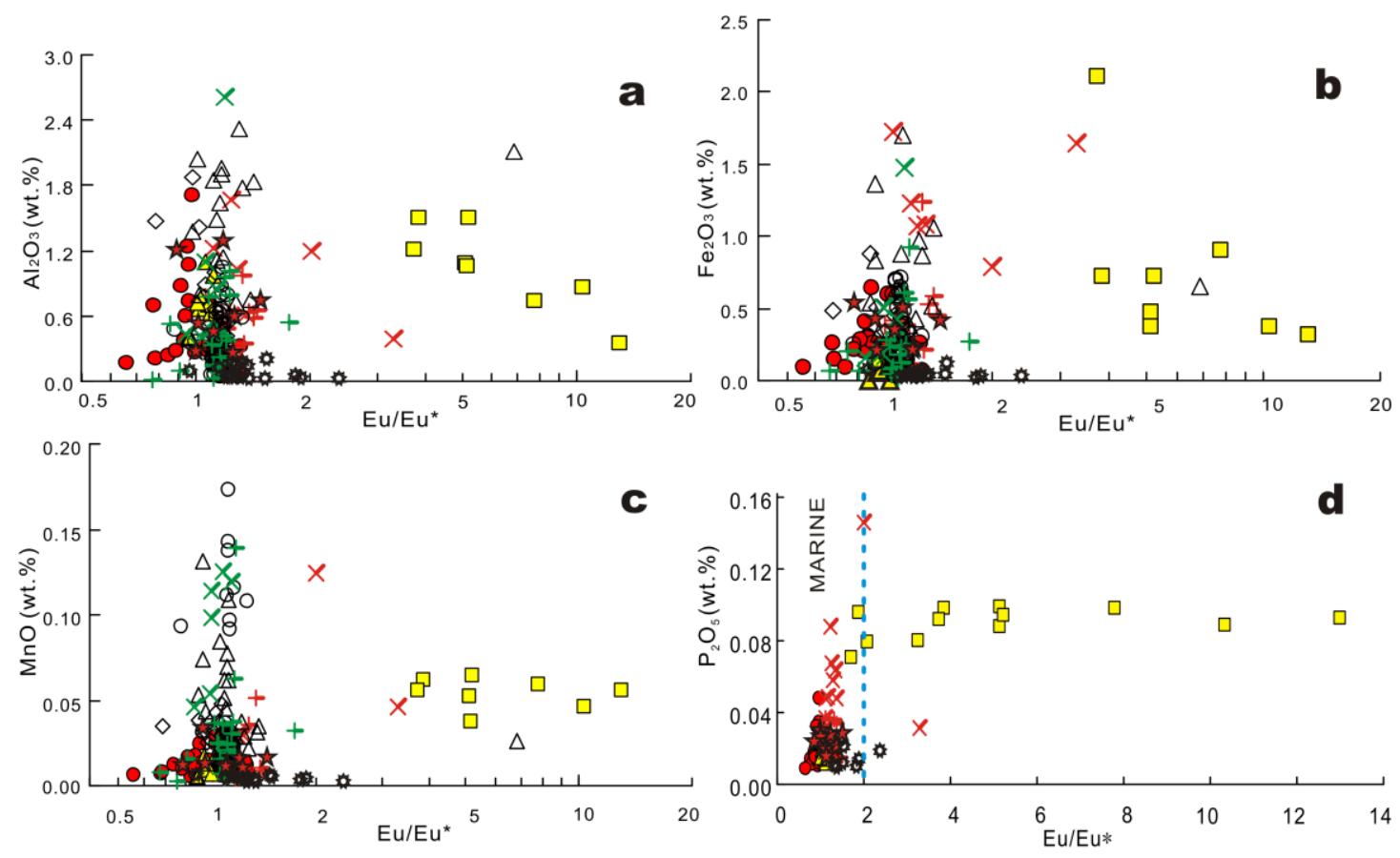

1161

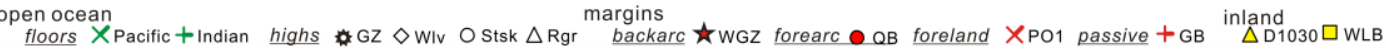

1162 


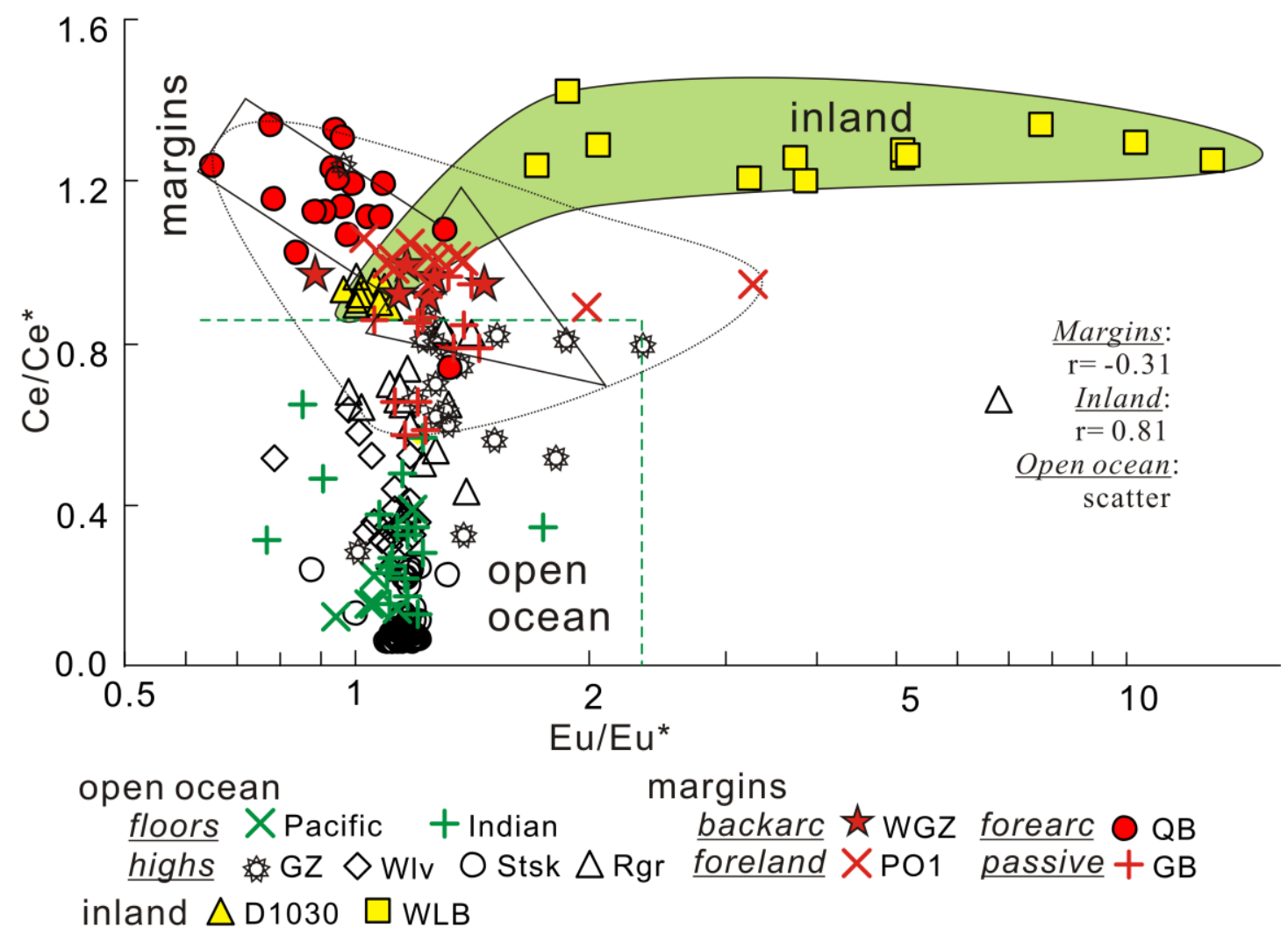

1164 

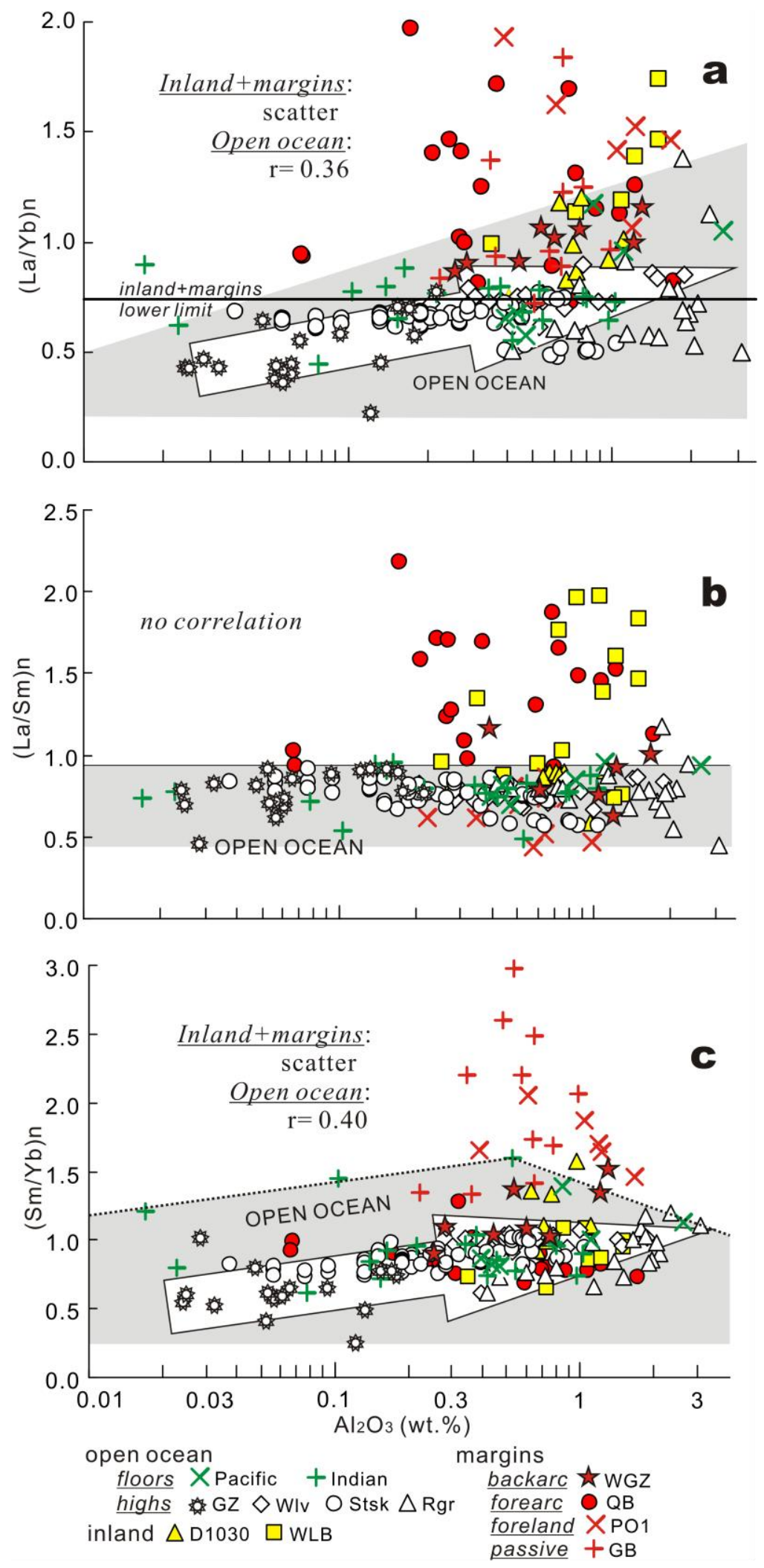

1165

1166 

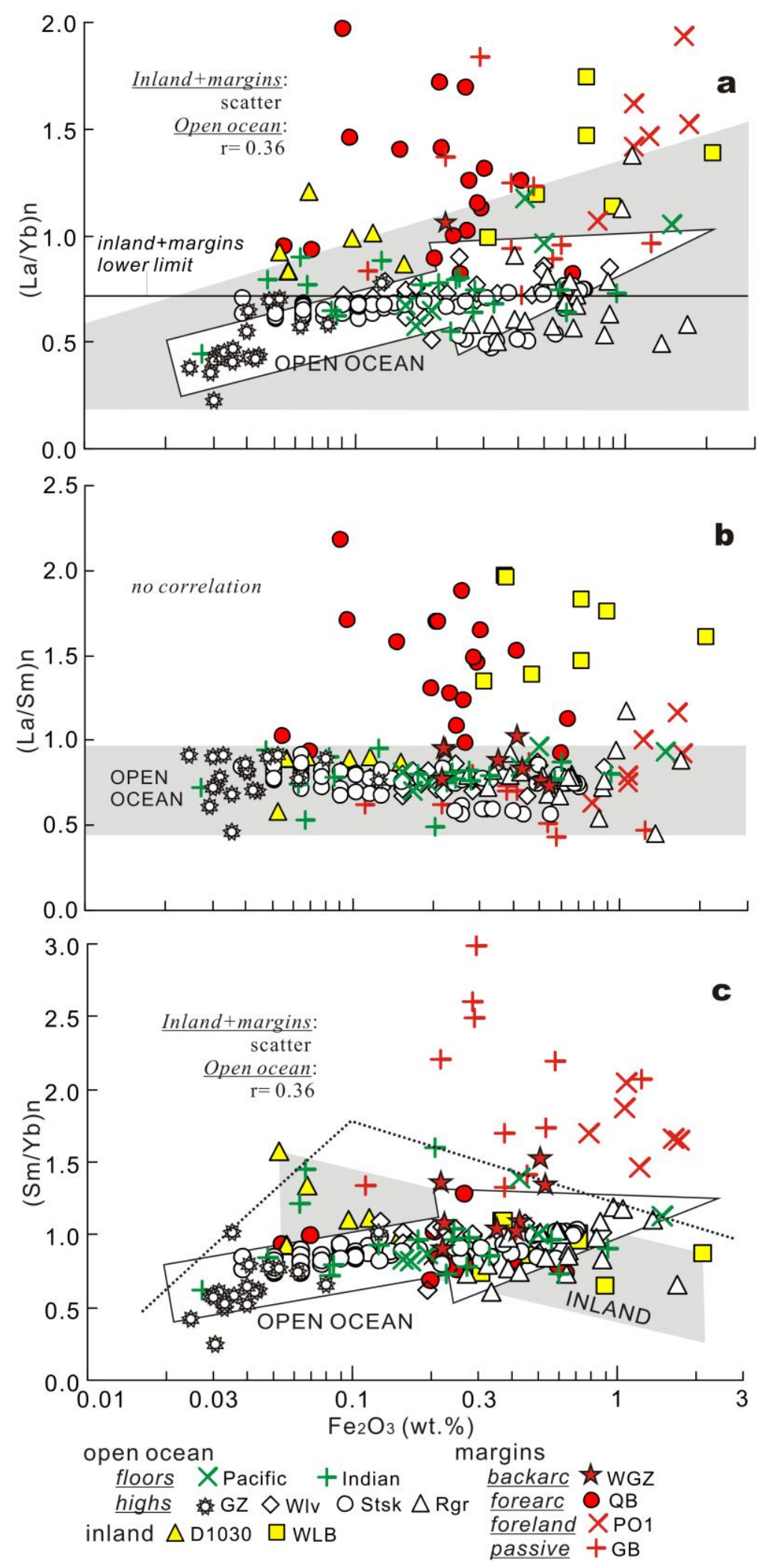

1168 

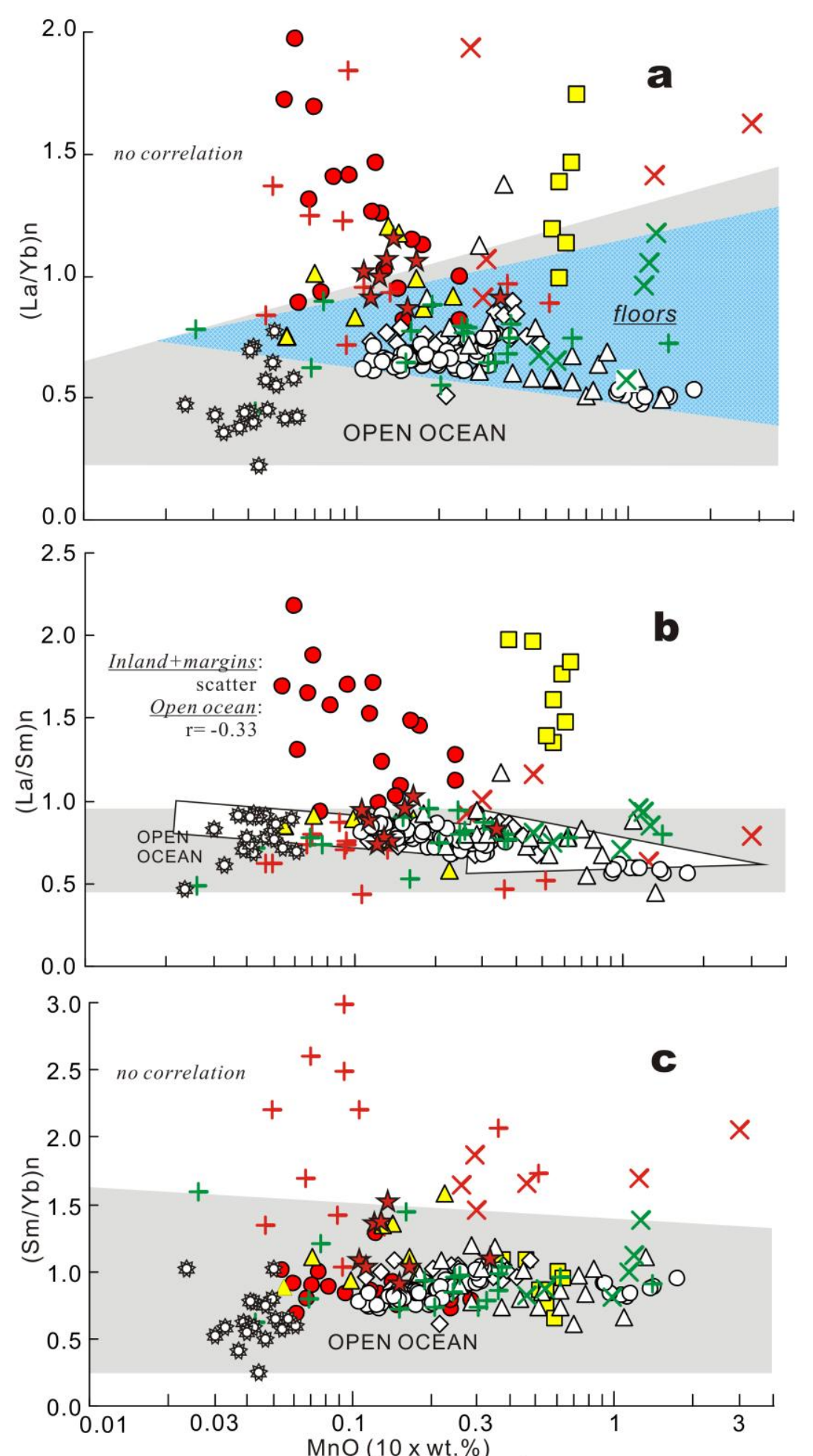

$$
\begin{aligned}
& \begin{array}{l}
\text { open ocean } \\
\text { floors } \times \text { pacific }+ \text { Indian } \quad \text { backarc } \downarrow \text { bains }
\end{array} \\
& \text { highs GZ } \diamond \text { WIv O Stsk } \triangle \mathrm{Rgr} \text { forearc } \mathrm{QQB} \\
& \text { inland } \triangle \mathrm{D} 1030 \square \mathrm{WLB} \quad \frac{\text { foreland }}{\text { passive }}+\mathrm{GB} 1
\end{aligned}
$$




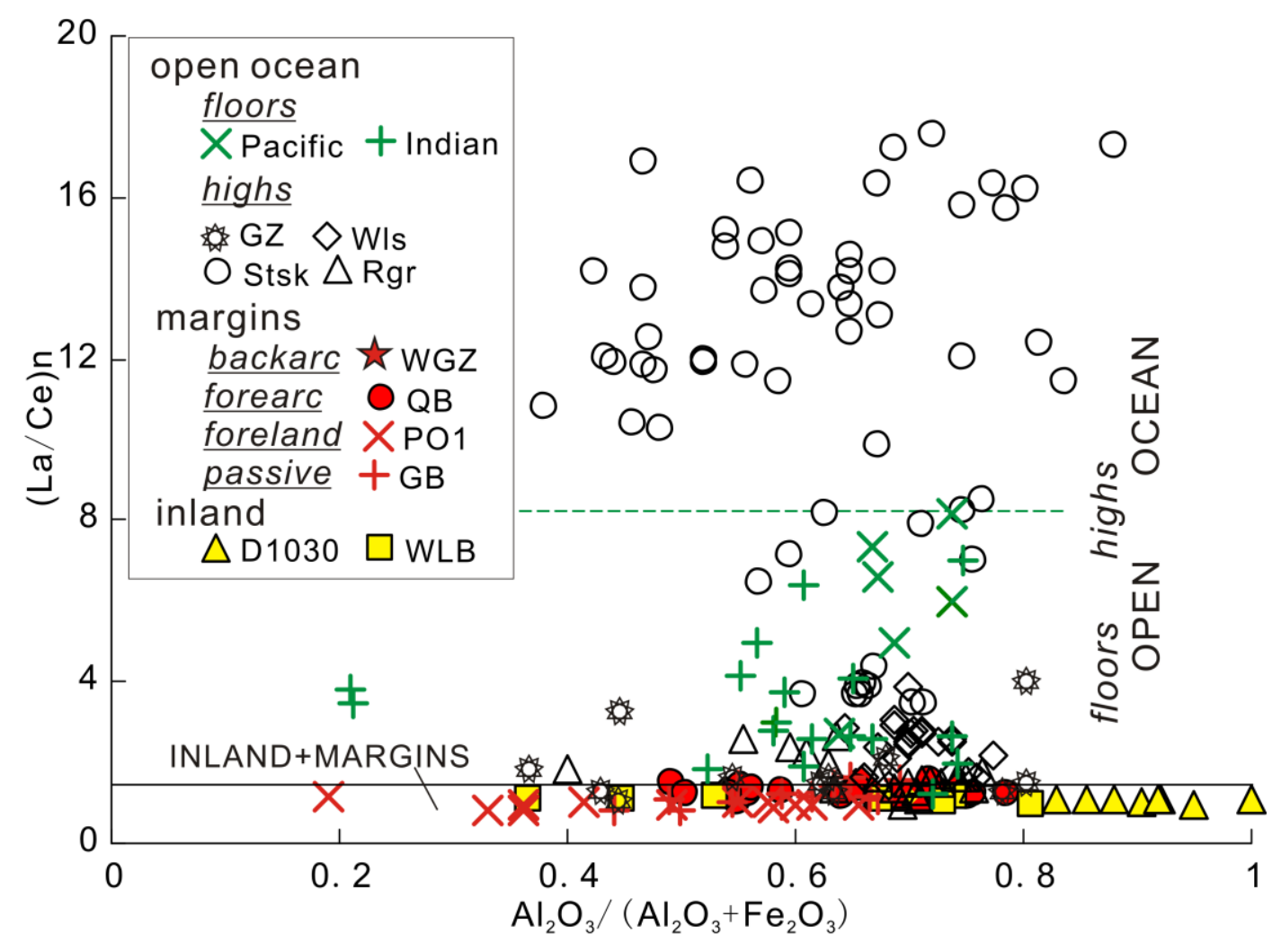

1172 

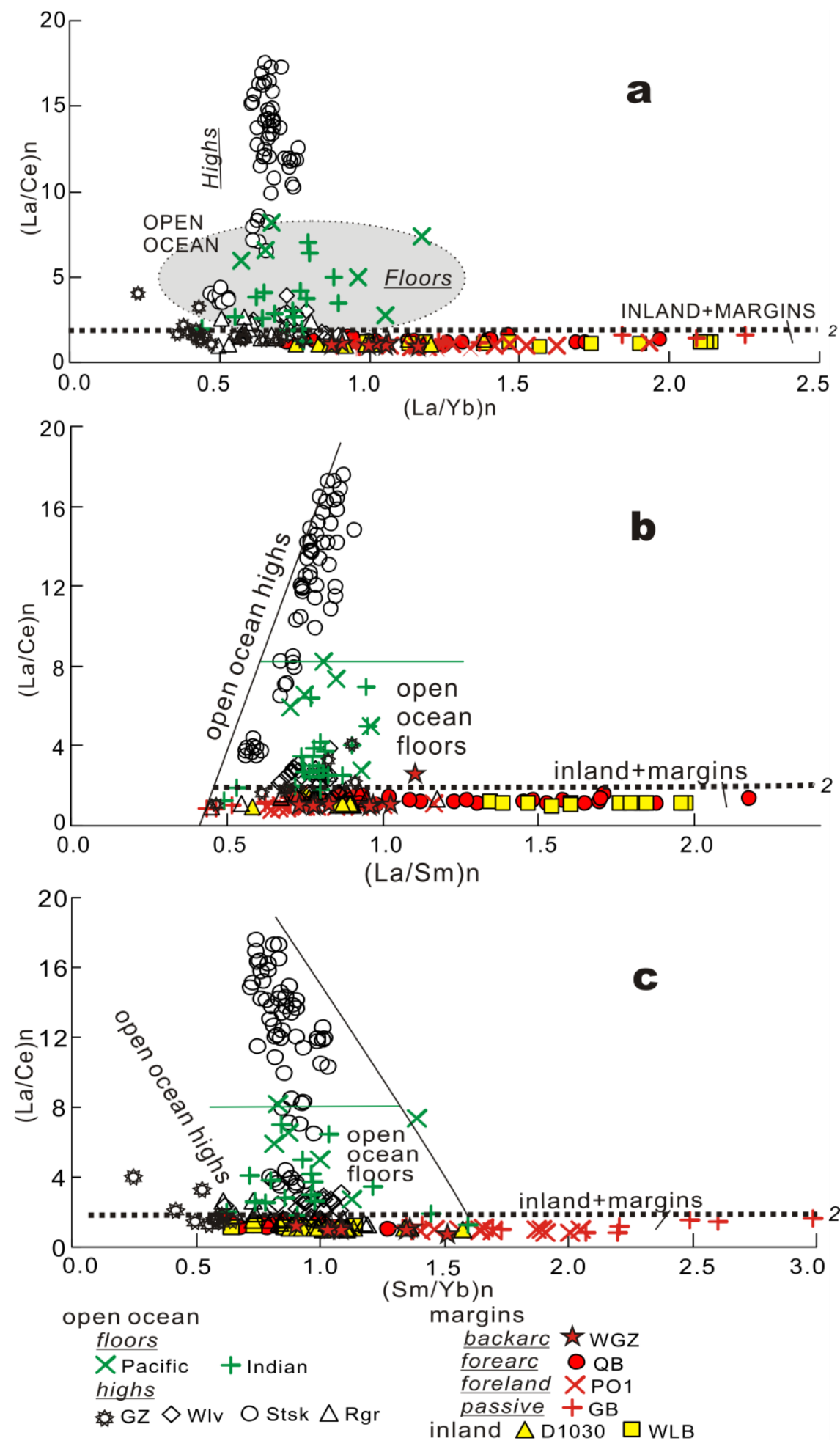

1174 

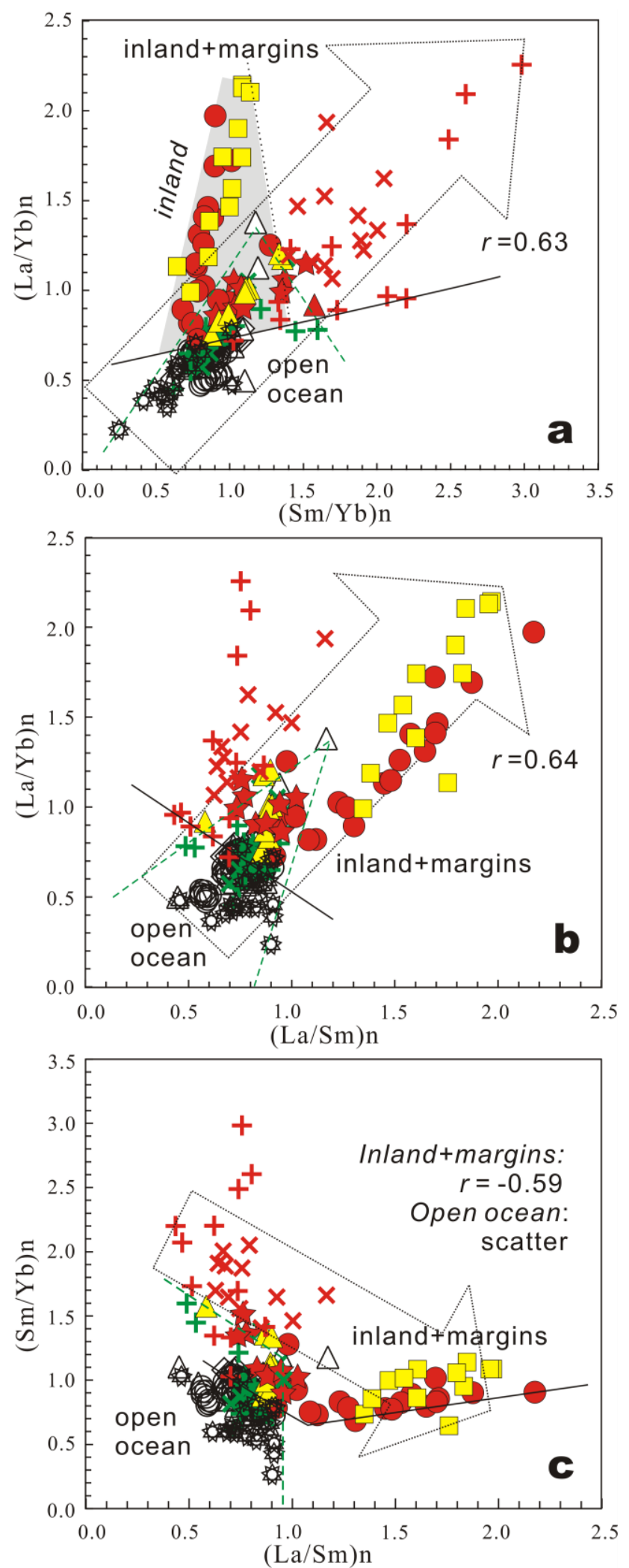

open ocean

floors XPacific +Indian

highs $\mathrm{GZ} \diamond \mathrm{Wlv} O$ Stsk $\triangle \mathrm{Rgr}$

margins

backarc 2 WGZ forearc $O \mathrm{QB}$

foreland XPO1 passive $+\mathrm{GB}$ inland $\triangle \mathrm{D} 1030 \square \mathrm{WLB}$ 

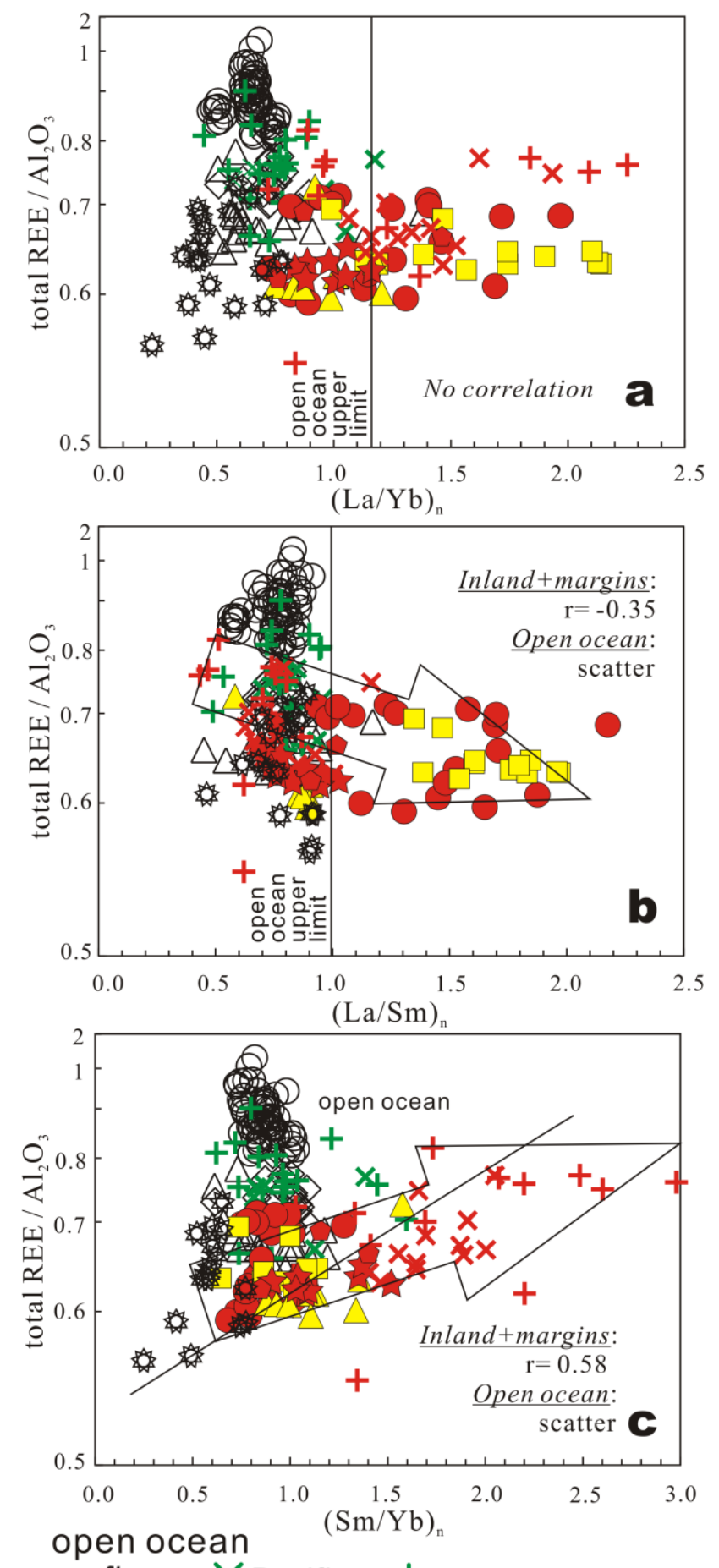

floors XPacific +Indian

$\underline{\text { highs }} \mathrm{GZ} \diamond \mathrm{Wlv} O$ Stsk $\triangle \mathrm{Rgr}$ margins backarc $\downarrow$ WGZ forearc $O \mathrm{QB}$ foreland XPO1 passive + $\mathrm{GB}$ inland $\triangle \mathrm{D} 1030 \square \mathrm{WLB}$ 


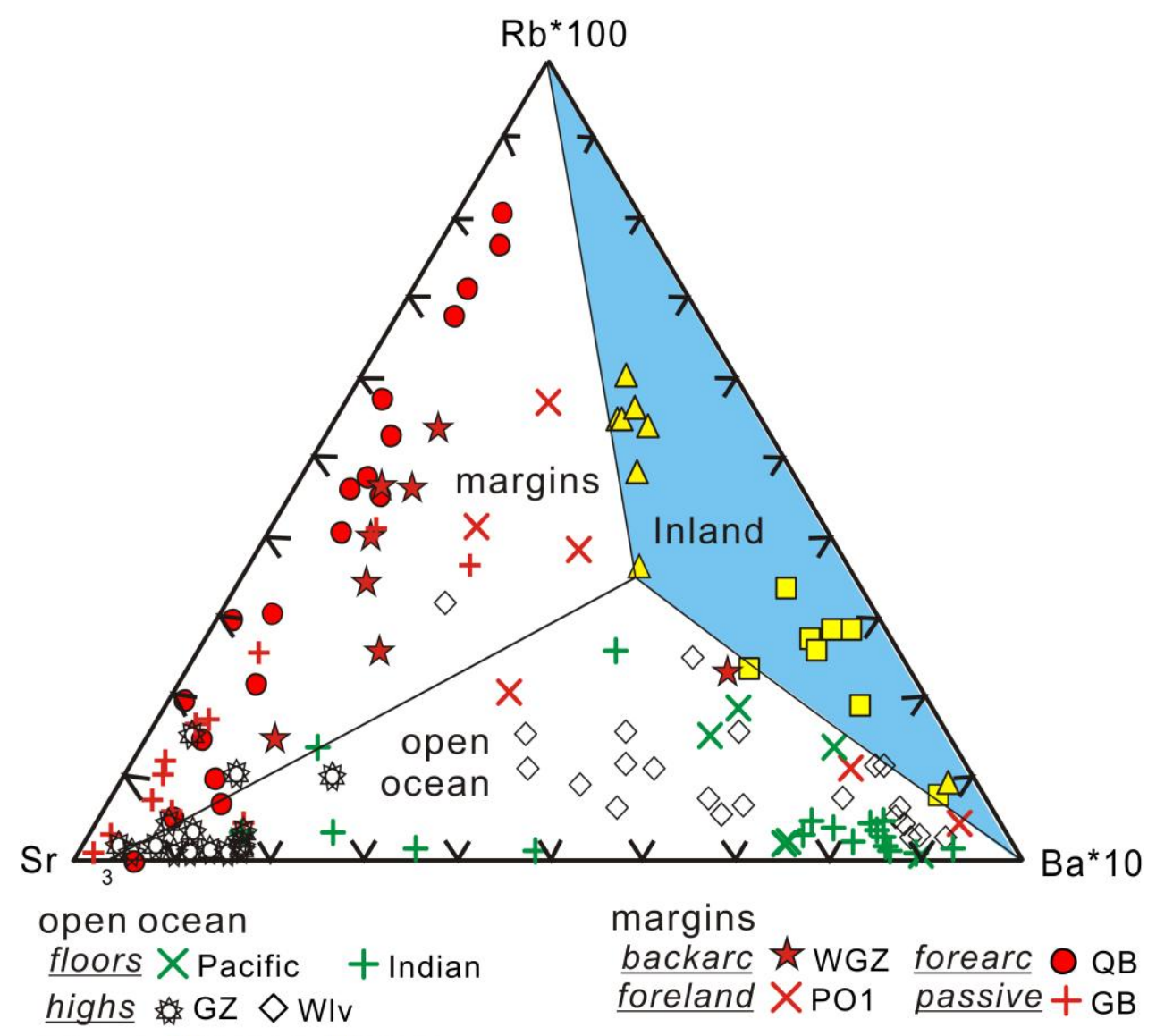

1179 inland $\triangle$ D1030 $\square$ WLB

1180 


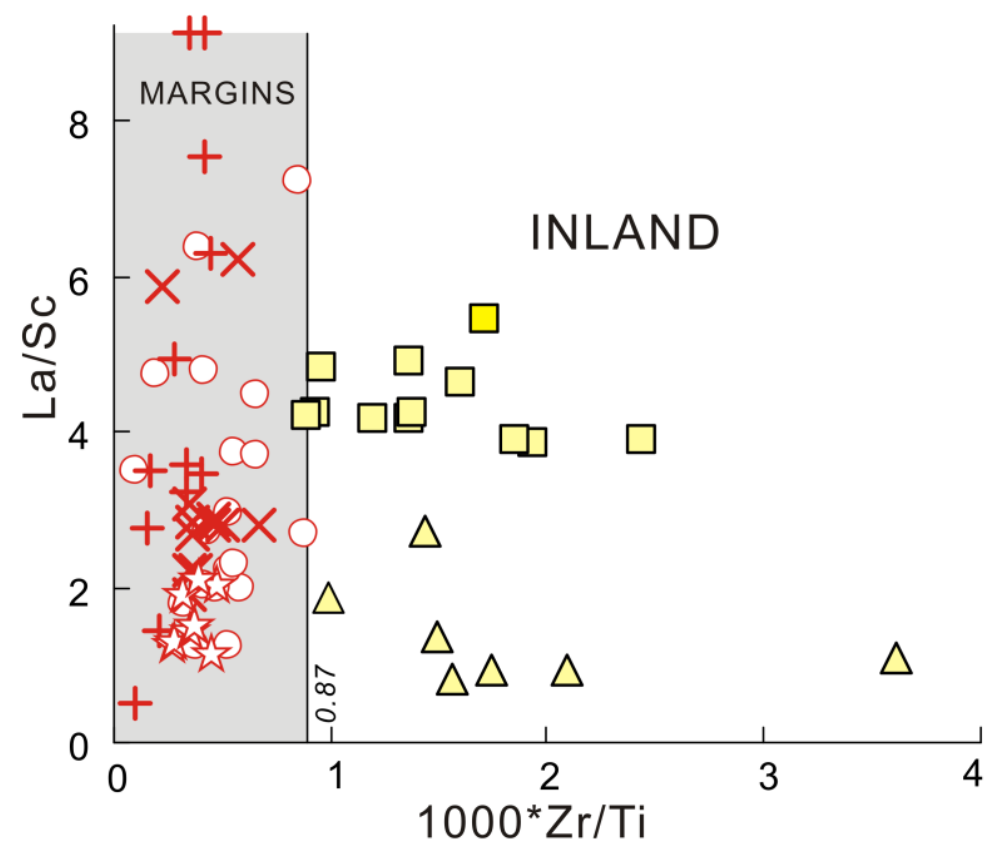

1181

inland margins

$\triangle \mathrm{D} 1030$ backarc $\boldsymbol{t}^{2} \mathrm{WGZ}$ forearc $\bigcirc \mathrm{QB}$

$\checkmark$ WLB foreland XPO1 passive + GB

1182 


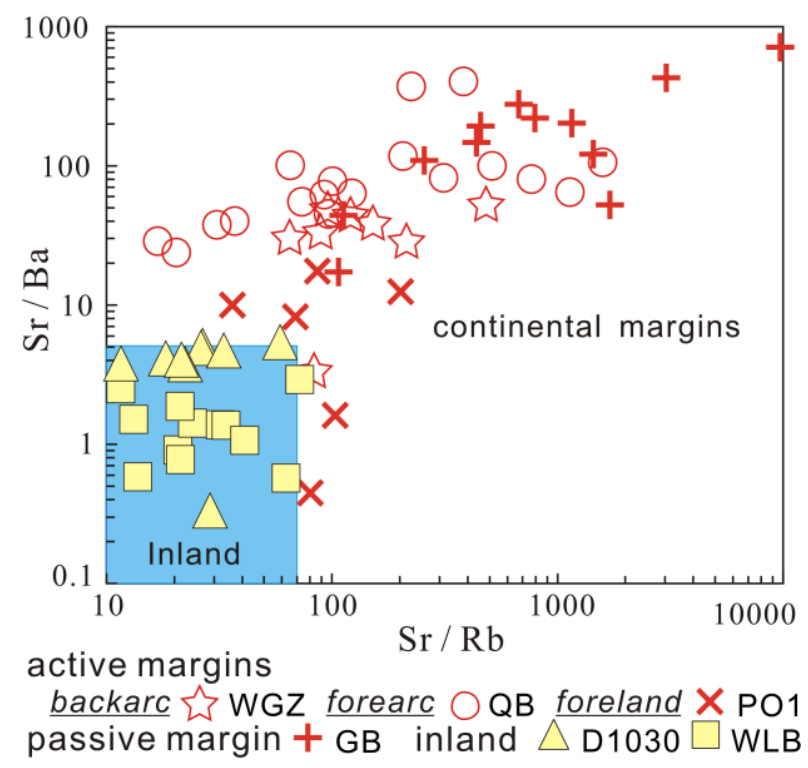

1183

1184 

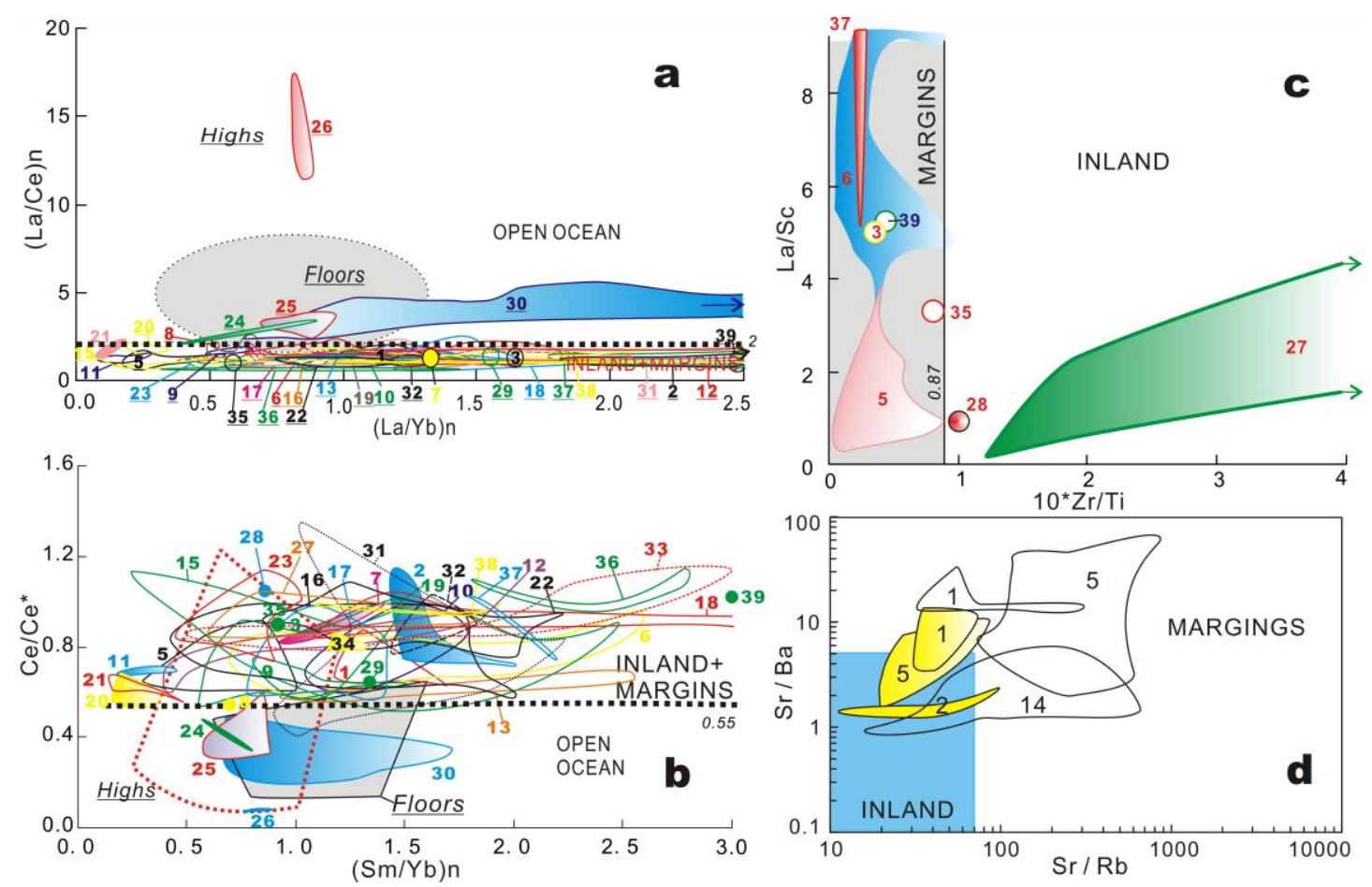
Table 1 Plate tectonic classification of basins for limestone

\begin{tabular}{|c|c|c|c|c|c|c|}
\hline Tectonic setting & $\begin{array}{l}\text { Dominant } \\
\text { depositional } \\
\text { basin }\end{array}$ & $\begin{array}{l}\text { Nature of } \\
\text { crust }\end{array}$ & $\begin{array}{l}\text { Characteristics } \\
\text { of } \\
\text { environment }\end{array}$ & $\begin{array}{l}\text { Source of } \\
\text { trace } \\
\text { elements }\end{array}$ & Studied basin & Reference \\
\hline \multicolumn{7}{|l|}{ Continental margin } \\
\hline $\begin{array}{l}\text { Unilaterally- } \\
\text { confined coastal } \\
\text { basin/passive } \\
\text { continental margin }\end{array}$ & $\begin{array}{l}\text { peri-cratonic } \\
\text { depocenters }\end{array}$ & $\begin{array}{l}\text { normal } \\
\text { continenta } \\
1 \text { crust }\end{array}$ & $\begin{array}{l}\text { extensional, } \\
\text { pericratonic, } \\
\text { stable }\end{array}$ & \multirow{4}{*}{$\begin{array}{l}\text { terrigenous } \\
\text { clasts, } \\
\text { seawater } \\
\text { adsorption, } \\
\text { hydrotherma } \\
\text { l plume }\end{array}$} & $\begin{array}{l}\text { Late Cretaceous Himalaya } \\
\text { (Dingri, GB in Fig.1b) }\end{array}$ & $\begin{array}{l}\text { Liu and Einsele } \\
\text { (1994) }\end{array}$ \\
\hline \multirow{3}{*}{$\begin{array}{l}\text { Bilaterally-confined } \\
\text { coastal basin/ active } \\
\text { continental margin }\end{array}$} & $\begin{array}{l}\text { back-arc } \\
\text { (rift) basin }\end{array}$ & $\begin{array}{l}\text { extended } \\
\text { continenta } \\
1 \text { crust }\end{array}$ & $\begin{array}{l}\text { extensional, } \\
\text { close to } \\
\text { volcanic arc }\end{array}$ & & $\begin{array}{l}\text { Mid-Cretaceous Lhasa } \\
\text { block (Cuoqin, WGZ in } \\
\text { Fig.1b) }\end{array}$ & $\begin{array}{l}\text { Zhang et al. } \\
(2004)\end{array}$ \\
\hline & $\begin{array}{l}\text { fore-arc } \\
\text { basin }\end{array}$ & $\begin{array}{l}\text { transitiona } \\
1 \text { crust }\end{array}$ & $\begin{array}{l}\text { extensional, } \\
\text { confined by } \\
\text { volcanic arc } \\
\text { and } \\
\text { subduction } \\
\text { zone }\end{array}$ & & \multicolumn{2}{|c|}{$\begin{array}{l}\text { Cretaceous Gangdese fore- Dürr (1996); } \\
\text { arc (Xigaze, QB in } \\
\text { Fig.1b) }\end{array}$} \\
\hline & $\begin{array}{l}\text { peripheral or } \\
\text { retroarc } \\
\text { foreland } \\
\text { basin }\end{array}$ & $\begin{array}{l}\text { thickened } \\
\text { continenta } \\
1 \text { crust }\end{array}$ & $\begin{array}{l}\text { contractional, } \\
\text { close to } \\
\text { mountain belt }\end{array}$ & & $\begin{array}{l}\text { Jurassic Qiangtang block } \\
\text { (Yanshiping, PO1 in } \\
\text { Fig.1b) }\end{array}$ & $\begin{array}{l}\text { Leeder et al. } \\
\text { (1988); Zhang } \\
\text { et al. }(2006 \mathrm{~b})\end{array}$ \\
\hline \multicolumn{7}{|l|}{ Open ocean } \\
\hline Oceanic floor & $\begin{array}{l}\text { ocenic floor } \\
\text { above } \\
\text { carbonate } \\
\text { compensatio } \\
\text { n depth }\end{array}$ & $\begin{array}{l}\text { normal } \\
\text { oceanic } \\
\text { crust }\end{array}$ & stable & $\begin{array}{l}\text { particulates } \\
\text { from } \\
\text { hydrotherma } \\
1 \text { plume, } \\
\text { seawater } \\
\text { adsorption }\end{array}$ & $\begin{array}{l}\text { Indian Ocean/ Pacific } \\
\text { Ocean (Fig.1a) }\end{array}$ & $\begin{array}{l}\text { Liu and Schmitt } \\
(1984,1990) \text {, } \\
\text { Michel et al. } \\
(1985), \text { Wang et } \\
\text { al. (1986), Liu } \\
\text { et al. (1988) }\end{array}$ \\
\hline Oceanic high & $\begin{array}{l}\text { oceanic } \\
\text { island, } \\
\text { oceanic } \\
\text { plateau, } \\
\text { aseismic } \\
\text { ridge }\end{array}$ & $\begin{array}{l}\text { thicken } \\
\text { oceanic } \\
\text { crust }\end{array}$ & $\begin{array}{l}\text { patch reefs, } \\
\text { liable to } \\
\text { oceanic } \\
\text { plateau } \\
\text { volcanism }\end{array}$ & & $\begin{array}{l}\text { Mid-Cretaceous Meso- } \\
\text { Tethys oceanic plateau } \\
\text { (Gaize, GZ in Fig.1b); } \\
\text { Walvis Ridge (Wlv in } \\
\text { Fig.1a) and Rio Grande } \\
\text { Rise (Rgr in Fig.1a) of } \\
\text { South Atlantic Ocean; } \\
\text { Shatsky Rise of Pacific } \\
\text { Ocean (Stsk in Fig.1a) }\end{array}$ & $\begin{array}{l}\text { Zhang et al. } \\
\text { (2014), Michel } \\
\text { et al. (1985), Hu } \\
\text { et al. (1988), } \\
\text { Liu and Schmitt } \\
\text { (1984) }\end{array}$ \\
\hline \multicolumn{7}{|l|}{ Land } \\
\hline Continental interior & inland lake & $\begin{array}{l}\text { extended } \\
\text { continenta } \\
1 \text { crust }\end{array}$ & $\begin{array}{l}\text { enclosed, } \\
\text { contractional }\end{array}$ & $\begin{array}{l}\text { terrigenous } \\
\text { clasts, } \\
\text { freshwater } \\
\text { adsorption }\end{array}$ & $\begin{array}{l}\text { Tertiary (Wuli, WLB in } \\
\text { Fig.1b) and Early } \\
\text { Cretaceous (Baishi, } \\
\text { P1030 in Fig.1b) Songpan- } \\
\text { Ganzi terrane }\end{array}$ & $\begin{array}{l}\text { Leeder et al. } \\
(1988) ; \\
\text { XZBGM } \\
\text { (1993); Wang et } \\
\text { al. (2008) }\end{array}$ \\
\hline
\end{tabular}


Table 2. Tectonic setting classification of various limestone suites for test of geochemical proxies

\begin{tabular}{|c|c|c|c|}
\hline \multicolumn{2}{|c|}{ No. Tectonic setting } & \multirow[t]{2}{*}{ Age } & \multirow[t]{2}{*}{ Reference } \\
\hline & Active continental margin & & \\
\hline $1^{\mathrm{a}}$ & Ft. Hays Limestone, Colorado, USA & Late Cretaceous & Cullers, 2002 \\
\hline $2^{\mathrm{a}}$ & limestone, Ruteh Formation, Kanigorgeh, NW Iran & Late Permian & $\begin{array}{l}\text { Abedini and Calagari, } \\
2015\end{array}$ \\
\hline $3^{\mathrm{a}}$ & Rohtas Limestone, Semri Group, Son Valley, Central India & Early Mesoproterozoic & Sen and Mishra, 2015 \\
\hline $4^{\mathrm{a}, \mathrm{b}}$ & Ukhrul Limestone of Assam-Arakan Basin, Manipur, NE India & Late Cretaceous to Eocene & Devi and Duarah, 2015 \\
\hline $5^{\mathrm{a}}$ & Alisitos Formation, Baja California, Mexico & Early Cretaceous & Madhavaraju et al., 2016 \\
\hline \multirow[t]{2}{*}{$6^{\mathrm{a}}$} & Mural Formation, Bisbee Group, Northern Sonora, Mexico & Aptian-lbian & Madhavaraju et al., 2010 \\
\hline & Passive continental margin & & \\
\hline $7^{\mathrm{a}}$ & Transvaal Supergroup, South Africa & Early Proterozoic & Klein and Beukes, 1989 \\
\hline 8 & Changxing Formation, Yangtze Craton, southern China & Early Triassic ( 240 Ma) & Liu et al., 1988 \\
\hline $9^{\mathrm{a}}$ & Shahabad Formation, Bhima Basin, Karnataka, southern India & Neoproterozoic & Nagarajan et al., 2011 \\
\hline 10 & Galicia Margin, North Atlantic & Cenozoic-Upper Jurassic & Liu et al., 1988 \\
\hline & Great Barrier Reef, Australia & Holocene & Webb and Kamber, 2000 \\
\hline 12 & Stromatolitic carbonates, Campbellrand platform, South Africa & Late Archean $(\sim 2.52 \mathrm{Ga})$ & Kamber and Webb, 2001 \\
\hline 13 & Orbata-Serdj Formations limestones, Central Tunisia & Early Cretaceous & Tlig and M'Rabet, 1985 \\
\hline $14^{\mathrm{b}}$ & limestone, Khashm Al-Raqaba area, El-Galala El-Qibliya, Egypt & Eocene & El Hefnawi et al., 2010 \\
\hline 15 & Krol and Bilara limestones, NW India & Late Neoproterozoic & Mazumdar et al., 2003 \\
\hline 16 & Microbialite, Demirtas, Turkey & Permian-Triassic transition & Loope et al., 2013 \\
\hline 17 & Microbialite, Cili, south China & Permian-Triassic transition & Loope et al., 2013 \\
\hline $18^{\mathrm{a}}$ & Kudankulam limestones, southern India & Late Miocene & $\begin{array}{l}\text { Armstrong-Altrin et al., } \\
2003\end{array}$ \\
\hline 19 & Reefal carbonates, Lennard Shelf, Canning Basin, Western Australia & Late Devonian & Nothdurft et al., 2004 \\
\hline $20^{\mathrm{a}}$ & $\begin{array}{l}\text { Mooidraai Formation Fe-rich limestone,Kalahari Manganese Field, } \\
\text { Transvaal Supergroup, South Africa }\end{array}$ & Palaeoproterozoic & Tsikos et al., 2001 \\
\hline 21 & Stromatolitic carbonates, Pilbara Craton, Australia & Archean $(\sim 3.45 \mathrm{Ga})$ & $\begin{array}{l}\text { Van Kranendonk et al., } \\
2003\end{array}$ \\
\hline $22^{\mathrm{a}}$ & $\begin{array}{l}\text { Yinkeng, Helongshan and Nanlinghu Formations, Chaohu, southern } \\
\text { China }\end{array}$ & Latest Permian-Lower Triassic & Chen et al., 2015 \\
\hline & Qixia Formation, Shizhu, Chongqing, southern China & Permian & Tian et al., 2014 \\
\hline & Open ocean & & \\
\hline & Cayman Brac & Cenozoic & Zhao and Jones, 2013 \\
\hline & Cismon limestone/marlstone couplets, Venetian, northern Italy & Albian-Cenomanian & Bellanca et al., 1997 \\
\hline 26 & Laytonville Limestone, central Franciscan Melange, western USA & Late Cretaceous ( 95 My) & Liu et al., 1988 \\
\hline
\end{tabular}

Inland

27 Fortescue Group, Pilbara Craton, western Australia

Neoarchaean (2.78-2.63 Ga) Bolhar and Van

28 Stromatolitic carbonate from the lacustrine Green River Formation, Eocene

Kranendonk, 2007 western United States

29 Lacustrine Kebar Formation, Central Tunisia

Bolhar and Van

Under debate $30^{\mathrm{a}}$

Limestone, Tieqiao section, Laibin, Guangxi province, south China $\quad$ Middle to Late Permian

Kranendonk, 2007

Tlig and M'Rabet, 1985

\section{Dolostone}

31 Orbata-Serdj Formations limestones, Central Tunisia (passive margin)

Early Cretaceous

Qiu et al., 2013

32 Orbata-Serdj Formations limestones, Central Tunisia (inland)

33 Transect from well BB-3 through well MM NW-7 to well ALNR-1, Oman (passive margin)

34 Cili, south China (passive margin)
Early Cretaceous

Ediacaran-Cambrian boundary

Permian-Triassic transition
Tlig and M'Rabet, 1985

Tlig and M'Rabet, 1985

Schroder and Grotzinger, 2007

Loope et al., 2013 
35 Semri Group, Son Valley, Central India (active margin)

36 Dashiqiao Formation, Liaohe Group, eastern Liaoning province,north China (active margin)

\section{Marble}

37 Marble, Hapschan Series, eastern Anabar Shield, Siberia (passive margin)

38

Impure marbles, Jiaobei terrane, Sulu UHP orogen, China (passive margin)
Early Mesoproterozoic

Early Proterozoic ( 2.2 Ga)

Sen and Mishra, 2015

Tang et al., 2009

Early Proterozoic ( 2.4 Ga) Condie et al., 1991

Middle Neoproterozoic ( 786 Tang et al., 2006 Ma)

39 Imnure marbles. Shuanghe Dabie UHP orogen. China (passive margin) Paleozoic

Xia et al. 2012

Notes : a, impure limestones (non-CaCO3 >10 wt.\%) are included; b, there are no data of rare-earth elments. 
Table 3. Average geochemical compositions of limestones deposited in various tectonic environments.

\begin{tabular}{|c|c|c|c|c|c|c|c|c|c|c|c|c|c|c|}
\hline & \multicolumn{2}{|c|}{ open ocean } & \multicolumn{2}{|c|}{ passive margins } & \multicolumn{2}{|c|}{ active margins } & \multicolumn{2}{|l|}{ margins } & \multicolumn{2}{|l|}{ marine } & \multicolumn{2}{|l|}{ Inland } & \multicolumn{2}{|l|}{ all } \\
\hline & avera & $\begin{array}{c}\text { e standard } \\
\text { deviatio }\end{array}$ & averc & $\begin{array}{l}\text { standar } \\
d\end{array}$ & avera & $\begin{array}{c}\text { e standard } \\
\text { deviatio }\end{array}$ & average & $\begin{array}{l}\text { standard } \\
\text { deviatio }\end{array}$ & average & $\begin{array}{l}\text { standard } \\
\text { deviatio }\end{array}$ & averas & $\begin{array}{c}\text { e standard } \\
\text { deviatio }\end{array}$ & average & $\begin{array}{l}\text { standard } \\
\text { deviatio }\end{array}$ \\
\hline & \multicolumn{2}{|c|}{$n=174$} & \multicolumn{2}{|c|}{$n=135$} & \multicolumn{2}{|l|}{$n=102$} & \multicolumn{2}{|l|}{$n=237$} & \multicolumn{2}{|l|}{$n=411$} & \multicolumn{2}{|l|}{$n=16$} & \multicolumn{2}{|l|}{$n=427$} \\
\hline $\mathrm{Al}_{2} \mathrm{O}_{3}$ & 0.47 & 0.55 & 0.44 & 0.61 & 0.81 & 0.89 & 0.60 & 0.77 & 0.54 & 0.69 & 0.89 & 0.34 & 0.56 & 0.68 \\
\hline $\mathrm{Fe}_{2} \mathrm{O}_{3}$ & 0.26 & 0.29 & 0.46 & 0.74 & 0.51 & 0.37 & 0.48 & 0.61 & 0.39 & 0.51 & 0.41 & 0.54 & 0.39 & 0.51 \\
\hline \multirow[t]{2}{*}{$\mathrm{MnO}$} & 0.04 & 0.04 & & & 0.09 & 0.09 & & & & & 0.03 & 0.02 & & \\
\hline & \multicolumn{14}{|l|}{ ppm } \\
\hline $\mathrm{Cr}$ & 5.99 & 7.99 & & & 9.60 & 7.81 & & & & & 9.06 & 5 & & \\
\hline $\mathrm{Sc}$ & 1.67 & 1.52 & & & 1.89 & 8.84 & & & & & 1.46 & 0.57 & & \\
\hline $\mathrm{La}$ & 12.47 & 10.72 & 3.63 & 4.60 & 3.69 & 3.49 & 3.66 & 4.15 & 7.34 & 8.76 & 3.48 & 2.38 & 7.19 & 8.64 \\
\hline $\mathrm{Ce}$ & 5.73 & 5.72 & 6.16 & 8.87 & 6.68 & 6.97 & 6.38 & 8.09 & 6.11 & 7.20 & 6.68 & 4.65 & 6.13 & 7.12 \\
\hline $\mathrm{Nd}$ & 12.07 & 11.75 & 3.18 & 3.96 & 3.47 & 4.07 & 3.30 & 4.00 & 6.96 & 9.24 & 2.03 & 1.85 & 6.78 & 9.12 \\
\hline $\mathrm{Sm}$ & 2.40 & 2.43 & 0.65 & 0.74 & 0.67 & 0.65 & 0.66 & 0.70 & 1.39 & 1.86 & 0.44 & 0.41 & 1.35 & 1.84 \\
\hline $\mathrm{Eu}$ & 0.61 & 0.64 & 0.14 & 0.17 & 0.17 & 0.16 & 0.15 & 0.16 & 0.34 & 0.49 & 0.30 & 0.25 & 0.34 & 0.48 \\
\hline $\mathrm{Tb}$ & 0.41 & 0.42 & 0.10 & 0.11 & 0.10 & 0.10 & 0.10 & 0.10 & 0.23 & 0.32 & 0.07 & 0.07 & 0.22 & 0.32 \\
\hline $\mathrm{Yb}$ & 1.37 & 1.39 & 0.26 & 0.22 & 0.31 & 0.27 & 0.28 & 0.24 & 0.74 & 1.06 & 0.21 & 0.14 & 0.72 & 1.05 \\
\hline \multirow[t]{2}{*}{$\mathrm{Lu}$} & 0.18 & 0.18 & 0.04 & 0.03 & 0.05 & 0.04 & 0.04 & 0.04 & 0.10 & 0.14 & 0.03 & 0.02 & 0.10 & 0.14 \\
\hline & \multicolumn{14}{|c|}{ Normalized to PAAS (Taylor and McLennan, 1985) } \\
\hline $\mathrm{Eu} / \mathrm{Eu}^{*}$ & 1.19 & 0.47 & 1.01 & 0.20 & 1.27 & 0.47 & 1.12 & 0.37 & 1.15 & 0.41 & 3.91 & 3.74 & 1.25 & 0.97 \\
\hline $\mathrm{Ce} / \mathrm{Ce}^{*}$ & 0.32 & 0.25 & 0.76 & 0.16 & 0.86 & 0.23 & 0.80 & 0.20 & 0.60 & 0.32 & 1.09 & 0.18 & 0.62 & 0.33 \\
\hline$[\mathrm{La} / \mathrm{Ce}]_{\mathrm{n}}$ & 6.07 & 5.06 & 1.42 & 0.41 & 1.21 & 0.25 & 1.33 & 0.36 & 3.34 & 4.05 & 1.09 & 0.04 & 3.25 & 4.00 \\
\hline$[\mathrm{La} / \mathrm{Sm}]_{\mathrm{n}}$ & 0.85 & 0.22 & 0.86 & 0.20 & 0.84 & 0.36 & 0.85 & 0.28 & 0.85 & 0.26 & 1.26 & 0.46 & 0.87 & 0.28 \\
\hline$[\mathrm{Sm} / \mathrm{Yb}]_{\mathrm{n}}$ & 0.89 & 0.20 & 1.12 & 0.59 & 1.04 & 0.41 & 1.08 & 0.52 & 1.00 & 0.43 & 1.03 & 0.24 & 1.00 & 0.42 \\
\hline$[\mathrm{La} / \mathrm{Yb}]_{\mathrm{n}}$ & 0.77 & 0.34 & 0.95 & 0.65 & 0.88 & 0.45 & 0.92 & 0.57 & 0.86 & 0.49 & 1.25 & 0.43 & 0.87 & 0.49 \\
\hline
\end{tabular}

